\title{
Effects of Shortening Replacement with Extra Virgin Olive Oil on the Physical-Chemical-Sensory Properties of Italian Cantuccini Biscuits
}

\author{
Angelo Maria Giuffrè * (D), Manuela Caracciolo, Marco Capocasale, Clotilde Zappia and Marco Poiana
}

\section{check for}

Citation: Giuffrè, A.M.; Caracciolo, M.; Capocasale, M.; Zappia, C.; Poiana, M. Effects of Shortening Replacement with Extra Virgin Olive Oil on the Physical-ChemicalSensory Properties of Italian Cantuccini Biscuits. Foods 2022, 11, 299. https://doi.org/10.3390/ foods11030299

Academic Editor: Antonella De Leonardis

Received: 2 January 2022

Accepted: 19 January 2022

Published: 23 January 2022

Publisher's Note: MDPI stays neutral with regard to jurisdictional claims in published maps and institutional affiliations.

Copyright: (C) 2022 by the authors. Licensee MDPI, Basel, Switzerland. This article is an open access article distributed under the terms and conditions of the Creative Commons Attribution (CC BY) license (https:// creativecommons.org/licenses/by/ $4.0 /)$.
Dipartimento di Agraria, Università degli Studi Mediterranea di Reggio Calabria, 89124 Reggio Calabria, Italy; manuela.caracciolo@unirc.it (M.C.); marcocapocasale@outlook.it (M.C.); czappia@outlook.it (C.Z.); mpoiana@unirc.it (M.P.)

* Correspondence: amgiuffre@unirc.it; Tel.: +39-327-7022840

\begin{abstract}
Olive oil is recognised for its beneficial effects on human health, mainly due to it containing oleic acid (a monounsaturated fatty acid), whereas fats of animal origin or margarine, which are often used in recipes for biscuit production, contain mainly saturated fatty acids. The aim of this study was to evaluate the shelf-life and physicochemical properties of biscuits and of the fats contained in original recipe Italian Cantuccini biscuits (50\% cow's butter and 50\% margarine). Additionally, the sensory properties of the biscuits were evaluated, including their colour, appearance, taste, flavour, texture and overall acceptability. At the same time, the fat composition of the original recipe was also modified to contain 30\% cow's butter and 70\% extra virgin olive oil, in order to replace an aliquot of the saturated fatty acid content with unsaturated fatty acids, in particular with one monounsaturated fatty acid, oleic acid. Colour (CIELab), water activity, relative humidity, hardness and fracturability analyses were conducted on Cantuccini biscuits. Colour (CIELab), free acidity, spectrophotometric characteristics, DPPH assay and fatty acid methyl ester (FAMEs) analyses were conducted on the fat extracted from Cantuccini biscuits prepared from both the original and modified recipes.
\end{abstract}

Keywords: bakery product; biscuit; Cantuccini; cookie; fat; lipid oxidation; shelf-life

\section{Introduction}

The global biscuits market is segmented by category into sweet biscuits and crackers and savoury biscuits. The global market was evaluated at USD 106.232 billion in 2020, and it is estimated to reach a compound annual growth rate of $4.97 \%$ during the period 2021-2026 [1]. Sweet biscuits include plain biscuits, cookies, sandwich biscuits, chocolatecoated biscuits and other sweet biscuits. Each country and region produces its own types of sweet biscuits, with their differences depending on the local availability of the ingredients used in their recipes.

Cantuccini are traditional sweet biscuits originally from Tuscany (Italy) but now found throughout Italy. They are dry biscuits that are filled with almonds, which are made by cutting slices of dough while still hot, before being the dough slices to the oven for a few minutes to reach their final consistency.

Cantuccini have a European Protected Geographical Indication (PGI) [2], which is attributed to products for which at least one of the stages of production, processing or preparation takes place in the region. The Italian product specification [3] includes the following requirements: the use of almonds (at least 17\%), crystalline or granulated sugar (20-40\%) and cow's butter (at quantities greater than 1.5\%). However, if the producer does not apply the PGI certification to their Cantuccini, the recipe can be modified.

Lipids in bakery products play a fundamental role from both technical and edible point of views. Lipids used in the bakery industry are oils or fats, which are respectively liquid or solid or semi-solid at room temperature. The differences in physical consistency 
are due to the triacylglycerol composition and in particular to the fatty acids and their melting points. Saturated fatty acids are solid or semi-solid at room temperature, whereas unsaturated fatty acids are liquid. The shorter the chain length and the lower the number of double bonds, the lower the melting point. Fats are easier to transport and less susceptible to oxidation than oils. At the same time, saturated fatty acids (SFAs), which are widely present in fats, and cholesterol (widely present in animal fats) are considered responsible for cardiovascular diseases [4]. The lipid content in biscuits usually ranges from 10 to $20 \%$ of the total weight, and consequently a daily portion of $50 \mathrm{~g}$ (i.e., 3-5 biscuits) contains 5-10 $\mathrm{g}$ of lipids. In light of the above, it is essential to reduce the amounts of saturated fats and animal fats in the human diet. In addition, it is well known that nowadays there is a high demand for high nutritional value foods. Extra virgin olive oil (EVOO) contains less than $0.5 \%$ cholesterol out of the total sterol content [5], 14-22\% SFAs out of the total fatty acid content [6,7], a good oleic/linoleic acid ratio [8] and antioxidants such as phenols and tocopherols [9]. EVOO is one of the most common foods in the Mediterranean diet, and in 2018 Calabria was the second Italian region for olive oil production (46,964 tons) out of the total Italian production of 264,101 tons [10].

From an edible point of view, the fat in biscuits is important for its nutritional value, for its tendency for oxidation and for the consequential radical formation. From a technical point of view, when fats are mixed with flour that has not yet been hydrated, particles of fats wrap around the particles of flour, reducing the dough's elasticity [11]. High elasticity is not advisable in biscuit dough because it causes the dough to shrink after lamination [12]. In studies on beaten pastry dough, fat was found to influence both the stability and size of air bubbles before baking and at initial baking stages [13-15]. In the initial baking process, fat prevents the coalescence of bubbles that are destroyed with the increase in baking temperature. The longer the bubbles remain in a dough, the larger the final volume of the baked products [16]. Fats can help leaven a product due to the incorporation of air [17].

In addition, fat has a lubricating action, which prevents the product from sticking to baking trays and causes the melting sensation when a biscuit is eaten.

To date in the literature, there have been no studies on the physical-chemical-sensory evolution of Cantuccini during storage. Scarce information exists on biscuits [18] and cookies [19] incorporated with EVOO as a total or partial shortening substitution.

The aim of this paper was to study the shelf-life of Cantuccini biscuits produced using the original recipe containing only cow's butter and margarine, as well as the effects of partial shortening replacement with extra virgin olive oil over one year's storage.

\section{Materials and Methods}

\subsection{Cantuccini Packaging}

Each package contained 35 biscuits weighing $200 \mathrm{~g}$ in total. For this experiment, biscuits were made using two recipes, which differed only in the type of fats or oils used. In the first (original) recipe, $7 \%$ fat was used (out of the total ingredients), at a ratio of $50 \%$ cow's butter to $50 \%$ margarine. In the second (modified) recipe, $11 \%$ fat was used (out of the total ingredients), at a ratio of 30\% cow's butter to $70 \%$ extra virgin olive oil. This modified recipe was applied after testing the consistency and pleasantness of the Cantuccini. This ratio was applied so as not to distort the type of product and to provide the right compromise between tradition and innovation. The shortening reduction led to the need for an increase in the EVOO to maintain the original characteristics of the biscuits as much as possible. The technical data on the packaging were: duplex laminate; width: $410 \mathrm{~mm}$; cut off: $285 \mathrm{~mm}$; thickness: $74 \mu \mathrm{m}$; material identification code: PP 5; core diameter: $76 \mathrm{~mm}$; outer diameter: $280 \mathrm{~mm}$; unit weight: $68.9 \mathrm{~g} / \mathrm{m}^{2}$; weight per pack: 8.05 g; heat sealing: both sides; oxygen barrier: very low $>150$; water vapour barrier: high (0.50-3.00); thermal treatment: none; composition: outer layer: COEXPP $30 \mu \mathrm{m}$; inner layer i.e., side in contact: COEXPP BL MAS $40 \mu \mathrm{m}$. 


\subsection{Cantuccini Preparation}

The original recipe (OR) for Cantuccini biscuits contained 50\% cow's butter and 50\% margarine. The modified recipe (MR) contained 30\% cow's butter and 70\% extra virgin olive oil. Sugar, margarine, butter and honey were placed in a mixer. The ingredients were mixed until smooth. At this point the eggs, baking powder and flour (00 type) were added. Finally, when the mixture was homogeneous, the whole almonds were added. The dough was kneaded until it was homogeneous, without lumps and of a good consistency. The dough was left for twenty minutes. At this point, pieces of dough weighing $2 \mathrm{~kg}$ were passed under the leveler before being cut into small pieces, which were placed in the baking pans and baked at $200{ }^{\circ} \mathrm{C}$ for $20 \mathrm{~min}$. The Cantuccini were removed from the oven and cooled to room temperature before packaging.

\subsection{Biscuits Analyses}

\subsubsection{Texture Analysis}

The hardness and fracturability of Cantuccini were determined using a texture analyzer (TA-XT2 Texture Analyzer, Stable Microsystems, Surrey, UK) equipped with a $25 \mathrm{~kg}$ load cell and a three-point bending rig (HDP/3PB). The parameters of hardness and fracturability were calculated as absolute values.

\subsubsection{Colour-Instrumental Determination}

Colour was determined using a colourimeter (Konica Minolta, model CM-A177) measuring $L^{*}$, Chroma $a^{*}\left(a^{*}\right)$ and Chroma $b^{*}\left(b^{*}\right)$. If a colour is expressed in CIELAB, $L^{*}$ denotes lightness, $a^{*}$ defines the red/green value and $b^{*}$ the yellow/blue value. In this experiment, colour determination was conducted on both the external (the top of the biscuit) and internal sides (the side of the cut) of Cantuccini biscuits.

\subsubsection{Water Activity (aw)}

Aw is the ratio between the vapour pressure of a food system when it is not influenced by the environment $(\mathrm{Pv})$ and the saturation vapour pressure of distilled water $(\mathrm{Pa})$ in the same conditions [20]. The aw determination was made at $20^{\circ} \mathrm{C}$ by means of an Aqualab Model series 3TE Decagon Devices, Inc. (Pullman, Washington, WA, USA).

\subsubsection{Relative Humidity (RH)}

The RH (moisture content) was determined according to the method proposed by [21], with heating at $103{ }^{\circ} \mathrm{C} \pm 2{ }^{\circ} \mathrm{C}$ until constant weight.

\subsubsection{Sensory Analysis}

A 20-member sensory panel was involved (ten men and ten women aged 19 to 60 years). The panelists were trained to consider six attributes, namely colour, appearance, taste, flavour, texture and overall acceptability. Each attribute was evaluated on a 10-point hedonic scale (1-10) ranging from 10 (like extremely) to 1 (dislike extremely) for each characteristic and with 5 representing minimum quality. The test was conducted in a sensory laboratory with individual booths and Cantuccini biscuits were given in white plates in a room prepared as suggested by 'Sensory Analysis-General Guidance for the Design of Test Rooms' [22]. The panelists conducted their evaluation in triplicate with a 2 day time lapse at $24{ }^{\circ} \mathrm{C}$ room temperature, with samples tempered for $60 \mathrm{~min}$. No odour and minimal noise were perceived by the panelists. The colour of the walls and furnishings in the testing area was white. Only one assessor was present, managing a group of five panelists in a 30 min session.

Colour expressed the degree of toasting. Appearance defined the shape of the biscuit. Taste and flavour defined the freshness of Cantuccini. Texture defined the crunchiness and overall acceptability was the sum of the previous five attributes. The sensory analysis was conducted prior to inform the panelists with regard to the Cantuccini composition. 


\subsection{Analysis of Fat}

\subsubsection{Fat Extraction}

Firstly, the almonds were separated from the biscuits and then reduced to a powder. Secondly, the lipid fraction was extracted from the powder of biscuits using a Soxhlet apparatus with $n$-hexane as the extracting solvent. Lastly, the solvent was evaporated using a Rotavapour apparatus under vacuum at $25^{\circ} \mathrm{C}$ and fat was stored until analyses [23].

\subsubsection{Determination of Colour}

A Minolta Chroma Meter CR-400 instrument and a Minolta transparent (base and side) special glass container $(5.0 \mathrm{~cm}, 6.0 \mathrm{~cm}$ high) with a cylindrical shape was used. One centimetre of fat was added to the glass container and the colour was determined. A further $1 \mathrm{~cm}$ was added and the colour was determined again. These two measurements were conducted in triplicate. The CIELab scale was used: $L^{*}$ (brigthness) ranges between 0 (black) and 100 (white); $a^{*}$ ranges between -90 (green) and +90 (red); $b^{*}$ ranges between -90 (blue) and +90 (yellow). The chroma was calculated using the formula discussed by Pathare et al. [24].

\subsubsection{Free Acidity (FA)}

A $1 \mathrm{~g}$ aliquot of the lipidic fraction was dissolved in a $50 \mathrm{~mL}$ ethanol/diethyl ether (1:1), after which titration was conducted with a $0.1 \mathrm{~N} \mathrm{NaOH}$ solution. The results were expressed as g oleic acid/100 g (Consleg, Annex II) [5].

\subsubsection{Spectrophotometric Indexes in the UV}

The lipid extract was dissolved in iso-octane and a $1 \%(w / v)$ and the solution was read at $232 \mathrm{~nm}, 266 \mathrm{~nm}, 268 \mathrm{~nm}$ and $274 \mathrm{~nm}$, in a double-ray Agilent spectrophotometer model 89090A (Santa Clara, CA, USA) (Consleg, Annex IX) [5].

\subsubsection{Antioxidant Activity (DPPH Assay on the Extracted Fat)}

The DPPH assay of the extracted fat was performed without extracting antioxidant compounds from the fat. It was conducted in an UV/Vis Spectrometer $\lambda_{2}$ from Perkin Elmer (Waltham, MA, USA) using the method proposed by Kalantzakis et al. [25], modified as follows. The fat was diluted with ethyl acetate $(1 / 10, v / v)$. Then, $0.25 \mathrm{~mL}$ of diluted oil was added to $2.25 \mathrm{~mL}$ of a $10^{-4} \mathrm{M}$ DPPH• solution, which was previously prepared with ethyl acetate. Thus, the absorbance of the mixture was immediately measured at $515 \mathrm{~nm}$ (abs t0) and after $30 \mathrm{~min}$ of shaking and incubation in the dark (abs $\mathrm{t} 30$ ). The $\%$ of inhibition was calculated as follows: ((abs t0 - abs t30)/abs t0) $) * 100$. The radical scavenging activity (\% of inhibition) was compared with a Trolox calibration curve and results were then expressed as TEAC values ( $\mu \mathrm{mol} \mathrm{TE} \cdot 100 \mathrm{~g}^{-1}$ of fat extracted).

\subsubsection{FAMEs}

An aliquot of the lipid fraction was methylated using the annex XB method A [5]. Gas chromatographic analysis of FAMEs was conducted as described in a previous work [26] and the results are expressed as $\% \mathrm{~m} / \mathrm{m}$.

\subsection{Statistical Analysis}

All analyses were carried out on three batches of Cantuccini biscuits, each one produced on a different day. For each batch, two replicates were conducted, each one from a different package. In brief, each result was the mean of six analyses. Means, standard deviations, $\mathrm{R}^{2}$ values and $r$ values were obtained using Excel 2010 software. The t-test was calculated at the $95 \%$ confidence interval. Analysis of variance (one-way ANOVA) and Tukey's tests were performed to determine the significance of differences. A $p$-value $<0.05$ was set as the significance level using SPSS software version 17.0. 


\section{Results and Discussion}

\subsection{Cantuccini Biscuits}

\subsubsection{Cantuccini Colour}

A colour analysis is a fast, easy and non-destructive test that can be applied to a bakery product. If the physicochemical and hedonic properties are considered, the first parameter used by a consumer in food acceptability is colour [27-29]. Changes in colour (both darkening and discolouration) during the biscuits' shelf-life influence the consumer's evaluation at the time of purchase [30,31]. In the studied biscuits, $L^{*}$ was highest in Cantuccini prepared with the original recipe; thereafter, the highest lightness value was found in the Cantuccini prepared with the modified recipe, showing a tendency to clear with time in biscuits prepared with $70 \%$ EVOO. The same initial trend but for a 4 month storage period was found for $L^{*}$ inside the biscuits (Table 1 ).

Table 1. Colours and $L^{*}$ values of Cantuccini biscuits made using the original recipe (OR; $50 \%$ butter $/ 50 \%$ margarine) and modified recipe (MR; $70 \%$ EVOO/30\% butter). One-way ANOVA, means $\pm \mathrm{SD}$ (of six replicates) in the same row followed by a different letter are significantly different according to Tukey's test; ${ }^{* * *} p<0.001$. Means in the same column are distinguished by capital letters. Means in the same line are distinguished by small letters.

\begin{tabular}{|c|c|c|c|c|c|c|c|c|}
\hline & T0 & $\mathrm{T} 2$ & $\mathrm{~T} 4$ & T6 & T8 & T10 & T12 & Sign. \\
\hline$L^{*}$ external OR & $56.59 \pm 2.37 \mathrm{aB}$ & $56.71 \pm 0.61 \mathrm{aB}$ & $51.65 \pm 6.04 \mathrm{aC}$ & $49.46 \pm 6.97 \mathrm{aB}$ & $52.7 \pm 0.51 \mathrm{aB}$ & $57.35 \pm 1.48 \mathrm{aB}$ & $51.13 \pm 3.72 \mathrm{aB}$ & n.s. \\
\hline$L^{*}$ external MR & $51.87 \pm 1.02 \mathrm{bB}$ & $53.37 \pm 0.16 \mathrm{bB}$ & $55.03 \pm 2.22 \mathrm{bB}$ & $58.7 \pm 3.95 \mathrm{bB}$ & $55.04 \pm 1.41 \mathrm{bB}$ & $65.70 \pm 0.36 \mathrm{aA}$ & $67.41 \pm 0.53 \mathrm{aA}$ & n.s. \\
\hline$L^{*}$ internal OR & $68.75 \pm 4.96 \mathrm{aA}$ & $66.73 \pm 5.38 \mathrm{aA}$ & $65.36 \pm 2.21 \mathrm{aA}$ & $69.25 \pm 1.87 \mathrm{aA}$ & $64.54 \pm 2.28 \mathrm{aA}$ & $60.65 \pm 0.77 \mathrm{aB}$ & $67.72 \pm 2.91 \mathrm{aA}$ & n.s. \\
\hline$L^{*}$ internal MR & $66.03 \pm 1.29 \mathrm{aA}$ & $55.88 \pm 0.30 \mathrm{bB}$ & $56.11 \pm 8.46 \mathrm{bB}$ & $69.94 \pm 0.65 \mathrm{aA}$ & $62.6 \pm 2.58 \mathrm{bA}$ & $66.72 \pm 2.86 \mathrm{aA}$ & $66.99 \pm 0.12 \mathrm{aA}$ & $* * *$ \\
\hline Sign. & $* * *$ & $* * *$ & $* * *$ & $* * *$ & $* * *$ & $* * *$ & $* * *$ & \\
\hline
\end{tabular}

Colour did not vary with the storage duration, except for $a^{*}(p<0.01)$ and $b^{*}(p<0.01)$ in the external measurement of the modified recipe (Tables 2 and 3). In almost all storage times, the $a^{*}$ value measured externally was higher in Cantuccini prepared with the OR than with the MR. This means that cow's butter and margarine lead to a reddening of the biscuits' external surface, but there is an inverse effect on the cut surface of the biscuits (internal side); in addition, on the external side of the MR Cantuccini, a decreasing tendency in $a^{*}$ values was found (Table 1 ).

Table 2. Colours and $a^{*}$ values of Cantuccini biscuits made using the original recipe (OR; $50 \%$ cow's butter $/ 50 \%$ margarine) and modified recipe (MR; 70\% EVOO/30\% cow's butter). One-way ANOVA, means \pm SD (of six replicates) in the same row followed by a different letter are significantly different according to Tukey's test; ${ }^{* * *} p<0.001$. Means in the same column are distinguished by capital letters. Means in the same line are distinguished by small letters.

\begin{tabular}{|c|c|c|c|c|c|c|c|c|}
\hline & T0 & T2 & $\mathrm{T} 4$ & T6 & T8 & T10 & T12 & Sign. \\
\hline$a^{*}$ external OR & $13.46 \pm 0.23 \mathrm{aA}$ & $12.96 \pm 0.25 \mathrm{aA}$ & $13.82 \pm 0.82 \mathrm{aA}$ & $12.61 \pm 1.22 \mathrm{aA}$ & $14.63 \pm 0.37 \mathrm{aA}$ & $12.63 \pm 1.12 \mathrm{aA}$ & $13.19 \pm 0.65 \mathrm{aA}$ & n.s. \\
\hline$a^{*}$ external MR & $13.86 \pm 1.27 \mathrm{aA}$ & $12.82 \pm 0.28 \mathrm{abA}$ & $12.00 \pm 0.10 \mathrm{abcA}$ & $13.65 \pm 0.77 \mathrm{abA}$ & $13.13 \pm 1.93 \mathrm{abA}$ & $11.08 \pm 0.57 \mathrm{bcA}$ & $10.45 \pm 0.12 \mathrm{cB}$ & $* *$ \\
\hline$a^{*}$ internal OR & $4.32 \pm 1.06 \mathrm{aB}$ & $4.56 \pm 0.46 \mathrm{aC}$ & $5.76 \pm 0.15 \mathrm{aB}$ & $4.96 \pm 1.27 \mathrm{aB}$ & $5.48 \pm 0.82 \mathrm{aB}$ & $6.69 \pm 1.79 \mathrm{aB}$ & $4.96 \pm 0.91 \mathrm{aC}$ & n.s. \\
\hline$a^{*}$ internal MR & $5.8 \pm 1.23 \mathrm{aB}$ & $6.90 \pm 0.60 \mathrm{aB}$ & $6.88 \pm 2.63 \mathrm{aB}$ & $5.43 \pm 0.16 \mathrm{aB}$ & $6.01 \pm 0.72 \mathrm{aB}$ & $5.48 \pm 0.48 \mathrm{aB}$ & $5.70 \pm 0.04 \mathrm{aC}$ & n.s. \\
\hline Sign. & $* * *$ & $* * *$ & $* * *$ & $* * *$ & $* * *$ & $* * *$ & $* * *$ & \\
\hline
\end{tabular}

The $b^{*}$ value measured externally was highest in OR Cantuccini until 4 months of storage, after which the highest values were generally found in MR Cantuccini. The $b^{*}$ value measured internally was almost always highest in MR Cantuccini and varied between a low of 27.55 to a high of 29.74 . The $b^{*}$ value measured in MR Cantuccini showed a very high significant decrease during storage $(p<0.001)$ (Table 3$)$. These values indicate the tendency for both OR and MR biscuits to turn more yellow in the last period of storage (Table 3). The chroma showed significant differences both during storage and between the different formulations on the internal and external sides. Chroma of the external side always showed higher values than those measured on the internal side (Table 4). 
Table 3. Colours and $b^{*}$ values of Cantuccini biscuits made using the original recipe (OR; $50 \%$ cow's butter/50\% margarine) and modified recipe (MR; 70\% EVOO/30\% cow's butter). One-way ANOVA, means \pm SD (of six replicates) in the same row followed by a different letter are significantly different according to Tukey's test; n.s., not significant; ${ }^{* *} p<0.01$; ${ }^{* * *} p<0.001$. Means in the same column are distinguished by capital letters. Means in the same line are distinguished by small letters.

\begin{tabular}{|c|c|c|c|c|c|c|c|c|}
\hline & T0 & T2 & T4 & T6 & T8 & T10 & T12 & Sign. \\
\hline$b^{*}$ external OR & $29.66 \pm 0.97 \mathrm{aA}$ & $30.24 \pm 0.40 \mathrm{aA}$ & $29.48 \pm 1.95 \mathrm{aA}$ & $27.48 \pm 3.25 \mathrm{aA}$ & $31.93 \pm 0.65 \mathrm{aA}$ & $31.58 \pm 2.49 \mathrm{aAB}$ & $27.8 \pm 3.26 \mathrm{aB}$ & n.s. \\
\hline$b^{*}$ external MR & $29.07 \pm 1.67 \mathrm{cA}$ & $29.80 \pm 0.30 \mathrm{cA}$ & $29.01 \pm 1.50 \mathrm{cA}$ & $30.13 \pm 1.30 \mathrm{cA}$ & $31.82 \pm 2.13 \mathrm{bcA}$ & $34.26 \pm 0.67 \mathrm{abA}$ & $35.96 \pm 0.17 \mathrm{aA}$ & $* * *$ \\
\hline$b^{*}$ internal OR & $23.03 \pm 1.21 \mathrm{aB}$ & $23.64 \pm 1.75 \mathrm{aC}$ & $26.99 \pm 2.01 \mathrm{aA}$ & $24.96 \pm 3.38 \mathrm{aA}$ & $25.18 \pm 1.68 \mathrm{aB}$ & $26.02 \pm 0.88 \mathrm{aC}$ & $25.83 \pm 1.58 \mathrm{aB}$ & n.s. \\
\hline$b^{*}$ internal MR & $28.54 \pm 1.82 \mathrm{aA}$ & $26.67 \pm 0.54 \mathrm{aB}$ & $26.35 \pm 1.11 \mathrm{aA}$ & $28.70 \pm 0.53 \mathrm{aA}$ & $29.74 \pm 0.68 \mathrm{aA}$ & $28.63 \pm 2.03 \mathrm{aBC}$ & $28.85 \pm 0.11 \mathrm{aB}$ & $*$ \\
\hline Sign. & $* *$ & $* * *$ & n.s. & n.s. & $* * *$ & $* *$ & $* * *$ & \\
\hline
\end{tabular}

Table 4. Colours and chroma values of Cantuccini biscuits made using the original recipe (OR; $50 \%$ cow's butter $/ 50 \%$ margarine) and modified recipe (MR; 70\% EVOO/30\% cow's butter). One-way ANOVA, means \pm SD (of six replicates) in the same row followed by a different letter are significantly different according to Tukey's test; ${ }^{*} p<0.05 ;{ }^{* *} p<0.01 ;{ }^{* * *} p<0.001$. Means in the same column are distinguished by capital letters. Means in the same line are distinguished by small letters.

\begin{tabular}{|c|c|c|c|c|c|c|c|c|}
\hline & T0 & T2 & T4 & T6 & T8 & T10 & T12 & Sign. \\
\hline Chroma external OR & $32.57 \mathrm{bA}$ & $32.90 \mathrm{bA}$ & $32.56 \mathrm{bA}$ & $30.24 \mathrm{cB}$ & $35.12 \mathrm{aA}$ & $34.01 \mathrm{aB}$ & $30.77 \mathrm{cB}$ & * \\
\hline Chroma external MR & $32.21 \mathrm{dA}$ & $32.44 \mathrm{dA}$ & $31.39 \mathrm{eA}$ & $33.08 \mathrm{cA}$ & $34.42 \mathrm{cAB}$ & $36.01 \mathrm{bA}$ & $37.45 \mathrm{aA}$ & ** \\
\hline Chroma internal OR & $23.43 \mathrm{dC}$ & $24.08 \mathrm{dC}$ & $27.60 \mathrm{aB}$ & $25.45 \mathrm{cC}$ & $25.77 \mathrm{cD}$ & $26.87 \mathrm{bD}$ & $26.30 \mathrm{bD}$ & * \\
\hline Chroma internal MR & $29.12 \mathrm{bB}$ & $27.55 \mathrm{cB}$ & $27.23 \mathrm{cB}$ & $29.21 \mathrm{bB}$ & $30.34 \mathrm{aC}$ & $29.15 \mathrm{bC}$ & $29.41 \mathrm{bBC}$ & * \\
\hline Sign. & $* *$ & ** & * & $* *$ & $* * *$ & $* * *$ & $* * *$ & \\
\hline
\end{tabular}

De Morais et al. [32] studied the storage stability of sweet biscuits prepared with recovered potato starch and found an initial $L^{*}$ increase ( $\left.36 \mathrm{~d}\right)$, a subsequent decrease until $144 \mathrm{~d}$ and a final increase to $180 \mathrm{~d}$; in the same study, in agreement with our results, a substantial increase in the $b^{*}$ value was found during the first 108 days, with a subsequent decrease up to $180 \mathrm{~d}$.

\subsubsection{Relative Humidity (RH)}

Moisture content plays a fundamental role in the manufacturing process of bakery products, including Cantuccini biscuits; furthermore, it influences their flavour, fragrance and consistency.

RH was always highest in OR Cantuccini, from 4.08 at T0 to 6.23 at T12, with a $52.7 \%$ increase in one year $(p<0.001)$, whereas RH in MR Cantuccini varied from 3.55 (T0) to 4.56 (T12), with a significant $28.5 \%$ increase $(p<0.001)$ in the same storage period (Figure 1a). It can be observed that Cantuccini prepared with the MR showed an initial lower RH than those prepared with the OR. Probably the different fat composition in OR (only butter and margarine) facilitated the absorption of moisture by the biscuits before being packaged. This process also continued after packing for two main reasons: (i) biscuits were not vacuum-packed and the package contained more or less $50 \%(v / v)$ of air included in the package at the time of sealing; (ii) a little vapour exchange also occurred during the one year of storage with the external atmosphere because the water vapour barrier of the packaging material used by the producer was high but not very high. It has to be pointed out that normally Cantuccini are consumed within 3-4 months of production, and in both the studied recipes RH showed low increases during the first six months, after which the increases were more evident (Figure 1a). 


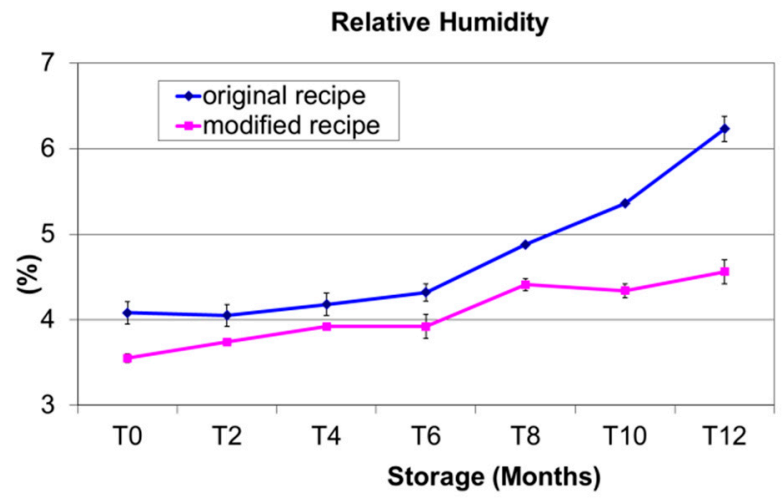

(a)

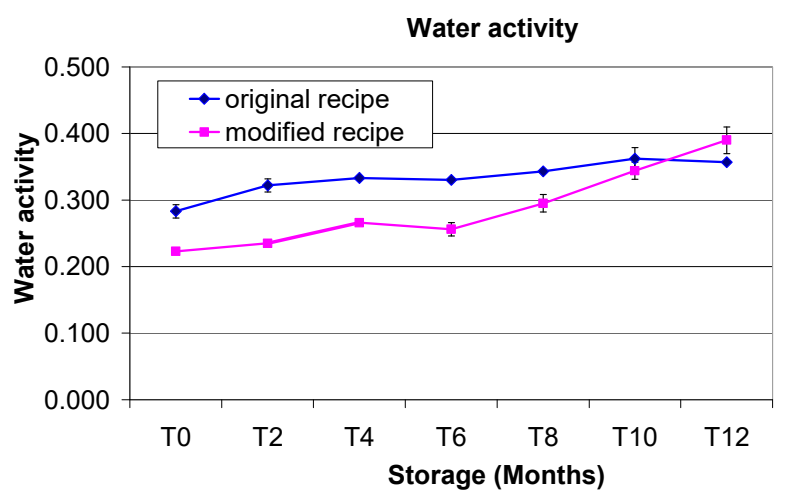

(b)

Figure 1. (a) Relative humidity of Italian Cantuccini biscuits prepared with the original recipe and the modified recipe during one year's shelf-life. (b) Water activity of Italian Cantuccini biscuits prepared with the original recipe and the modified recipe during one year's shelf-life.

The initial RH values (T0) were confirmed by findings of Robertson [33], who found $1-5 \%$ of $\mathrm{RH}$ in just-baked biscuits after cooling at room temperature. Dried products are characterised by hygroscopic behaviour, which causes water absorption influenced by the atmosphere and the packaging materials. Other authors found $\mathrm{RH}$ increases ranging from $2 \%$ to $5.56 \%$ in a $105 \mathrm{~d}$ experiment with different packaging materials. They pointed out that the biscuits packed with film containing poly lactic acid were the most sensitive to RH absorption [34]. Similar behaviour was found by Chowdhury et al. [35], who over 3 months' storage of local and foreign biscuits, found constant RH increases of between 1 and 5.34\% (T0) and between 2.81 and $4.64 \%$ at the end of the study. In agreement with the Cantuccini analyses, a constant increasing aw trend was found by other authors who studied biscuits prepared with wheat flour or alternatively corn, sunflower or high-oleic sunflower oil [36].

\subsubsection{Water Activity (aw)}

The aw showed very high and significant increasing trends in both recipes (Figure 1b). In detail, the highest aw value was found in OR Cantuccini with 10 months' storage, while only on the last storage date was the aw higher in MR Cantuccini. Overall, in biscuits prepared with OR, aw moved from a low of 0.283 at T0 to 0.357 at T12 $(p<0.001)$, whereas in MR Cantuccini, the values moved from 0.223 (T0) to 0.390 (T12) $(p<0.001)$. Data for aw were found to be correlated with RH values as follows: $\mathrm{R}^{2}=0.5636$ and $r=0.7507$ for OR; $\mathrm{R}^{2}=0.8527$ and $r=0.9234$ for MR. As with $\mathrm{RH}$, for aw the values also increased slightly for the first 6 months and more consistently from the 6th to the 12th month.

This is in agreement with the findings of Hough et al. [37], who found a positive correlation between $\mathrm{RH}$ and aw in a study on different bakery products, including toasted bread, crackers from whole-wheat flour, crackers from normal flour and vanilla-flavoured sweet biscuits.

The modified Cantuccini recipe contains reduced amounts of both the RH and aw (Figure 1a,b). This was due to the capacity of shortening to coat the gluten network and starch particles in dough with an extensible film during mixing, which reduces the water hydration capacity of the dough [38]. Margarine and cow's butter contain 10-15\% water, whereas EVOO does not contain water. This could explain the major hydrophobic behaviour of MR with respect to OR and the lower $\mathrm{RH}$ and aw values.

These values were lower than those found in Amaretti cookies (0.64-0.80) that were individually packaged in a high water vapour barrier film and stored for 120 days [39]. The increasing trend for aw in Cantuccini worsens the shelf-life, even if the aw values in both recipes remained always well within the range of $0.6-0.8$, which is a critical factor for the growth of moulds [40]. 


\subsubsection{Cantuccini Texture}

Texture is often considered by consumers at a subconscious level. The evaluation of the texture is not immediate because consumers often concentrate initially on flavour [41]; however, if the biscuit is not crisp and crunchy and is instead stale it will be rejected, even if the flavour is excellent.

Crispy is defined as, "A dry, rigid food, which when bitten with the incisors, fractures quickly, easily and totally, while emitting a relatively loud, high-pitched sound", whereas crunchy is defined, "A dense-textured food, which when chewed with the molars, undergoes a series of fractures while emitting relatively loud, low-pitched sounds" [42].

Hardness values decreased constantly over the 12 month storage period for both fat formulations. These values varied between a low of 3659 and a high of 5619 in the MR biscuits and between 2723 and 6150 in the OR biscuits, increasing by 2.25 times in the OR $(p<0.001)$ and 1.54 times in the MR Cantuccini $(p<0.05)$ (Figure 2a). The hardness value in the control (T0) was higher in the OR, although after two months' storage (T2) the OR values were always lower than the MR ones. This means that the recipe variation, with the addition of extra virgin olive oil, the elimination of margarine and the reduction in cow's butter content, produced a biscuit that maintained greater hardness during its shelf-life (Figure 2a).

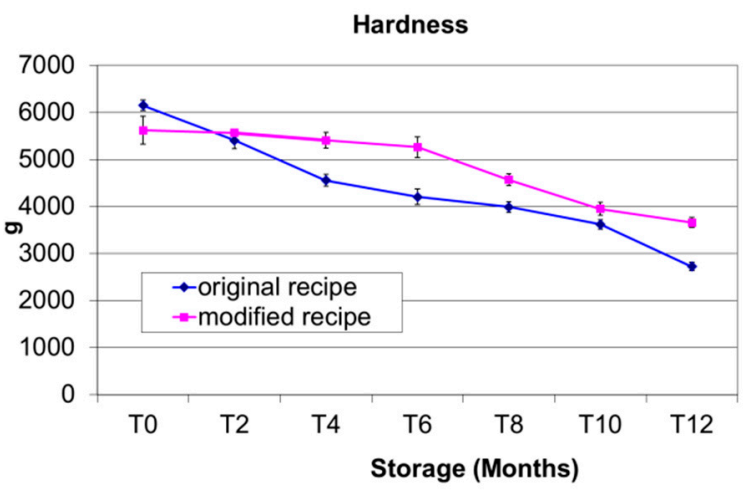

(a)

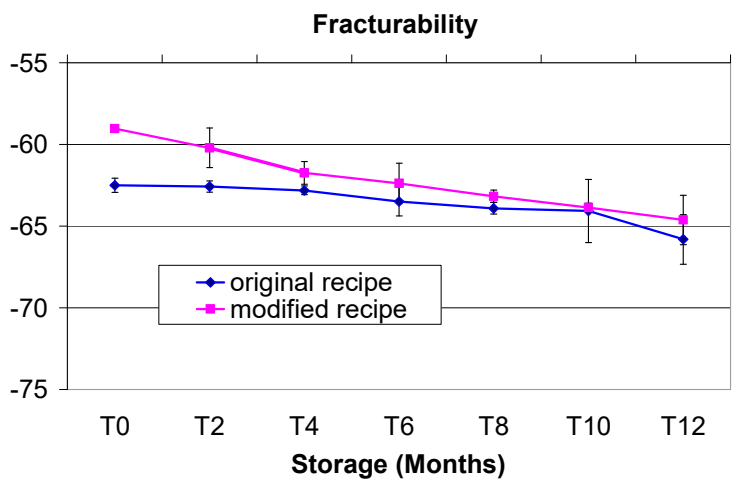

(b)

Figure 2. (a) Hardness of Italian Cantuccini biscuits prepared with the original recipe and the modified recipe during one year's shelf-life. (b) Fracturability of Italian Cantuccini biscuits prepared with the original recipe and the modified recipe during one year's shelf-life.

Hough et al. studied different bakery products and found a negative correlation between aw and texture, as well as differences in relations to the biscuit composition and the type of flour [37]. Piga et al. studied the evolution of typical Italian 'Amaretti' cookies during storage and found a better response in term of delays in hardening in cookies packaged with an aluminium foil with respect to cookies wrapped in polyvinylchloride. They explained that this was possibly due to water redistribution, with consequent sucrose crystallization and a consequent change to a mealy texture from a soft and moist one [43].

Fracturability value was determined as the distance taken by the probe until the point of fracture.

Fracturability values showed a non-significant decrease with storage for the OR and a significant decrease $(p<0.05)$ for the MR (Figure $2 b)$, reflecting a lowering of the friability, which is negative for biscuits in terms of consumer acceptability.

Our results are similar to the findings by Jacob and Leelavathi [44], who studied biscuits prepared with refined wheat flour and alternative fats, including (i) emulsified bakery shortening, (ii) emulsified margarine, (iii) non-emulsified hydrogenated vegetable fat and (iv) sunflower oil, and found that cookies containing liquid oil in the recipe had a relatively harder texture compared to bakery shortening and hydrogenated fat. A similar 
decreasing trend in hardness and fracturability values was also described by Balestra et al. [34] in biscuits prepared with sunflower oil and stored for 120 days.

Two of the most important parameters influencing hardness and fracturability are aw and RH, which were found to be inversely correlated with hardness. These data are explained by the Pearson test and t-test. In the OR Cantuccini, the higher the aw the lower the hardness $\left(\mathrm{R}^{2}=0.8498 ; r=-0.9218 ; \mathrm{t}=10.2123 ; p=0.000\right)$, and the higher the $\mathrm{RH}$ the lower the hardness $\left(\mathrm{R}^{2}=0.7713 ; r=-0.8782 ; \mathrm{t}=10.2020 ; p=0.000\right)$. Similarly, in the MR Cantuccini, the higher the aw the lower the hardness $\left(\mathrm{R}^{2}=0.9580 ; r=-0.9797 ; \mathrm{t}=15.9785\right.$ : $p=0.000)$, and the higher $\mathrm{RH}$ the lower the hardness $\left(\mathrm{R}^{2}=0.9092 ; r=-0.9535 ; \mathrm{t}=15.9670\right.$; $p=0.000)$.

Findings from other authors reported higher fracturability values $(p \leq 0.05)$ for formulations containing potato and corn starch with respect to biscuits prepared without eggs and without carob syrup. These results were explained by the looser matrix formation in potato and corn starch formulations, which contained lower levels of proteins [45]. TorresGonzález et al., in a study on Colombian lemon biscuits, described a positive and highly significant correlations $(p<0.01)$ between fracturability and firmness $(r=0.973)$, consistency $(r=0.933)$ and maximum strength (hardness) $(r=1)$, with a moderate correlation $(p<0.05)$ between fracturability and stiffness $(r=0.405)$ [46].

\subsubsection{Cantuccini Sensory Analysis}

The sensory characteristics analysed by the panelists decreased during storage, although with different trends for OR Cantuccini and MR.

The panelists preferred the colour of OR Cantuccini for the first 8 months of storage, whereas the colour of MR Cantuccini was better evaluated from T10. At T12, the colour of the OR biscuits was considered to be of minimum acceptable quality (Figure 3a).

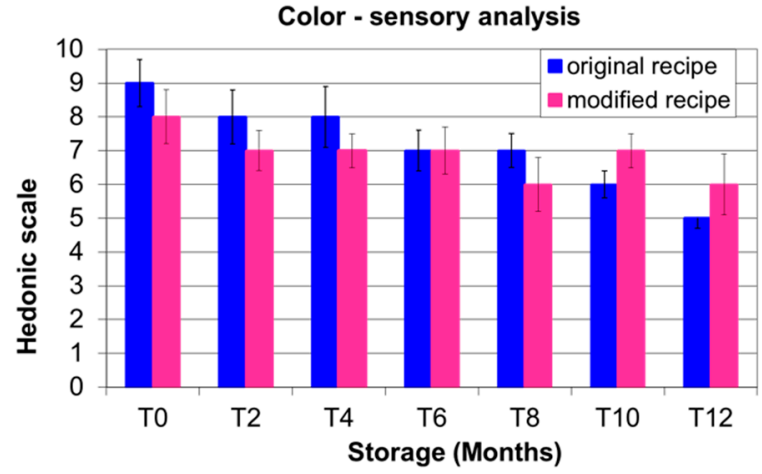

(a)

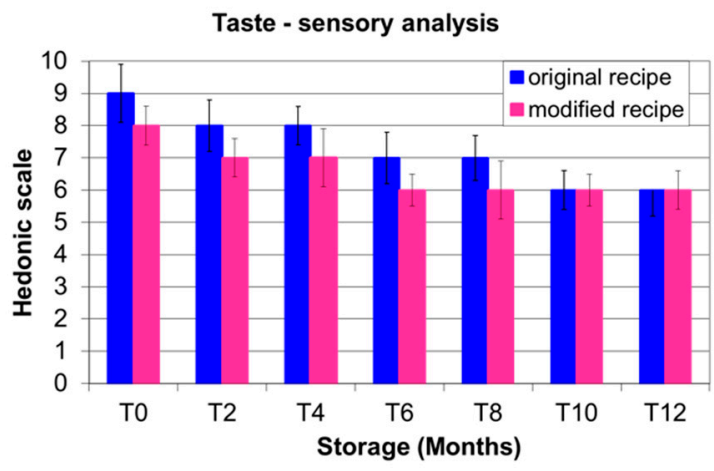

(c)

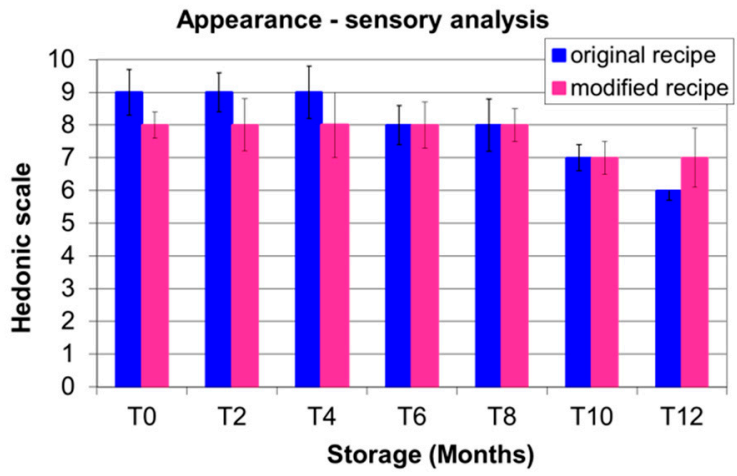

(b)

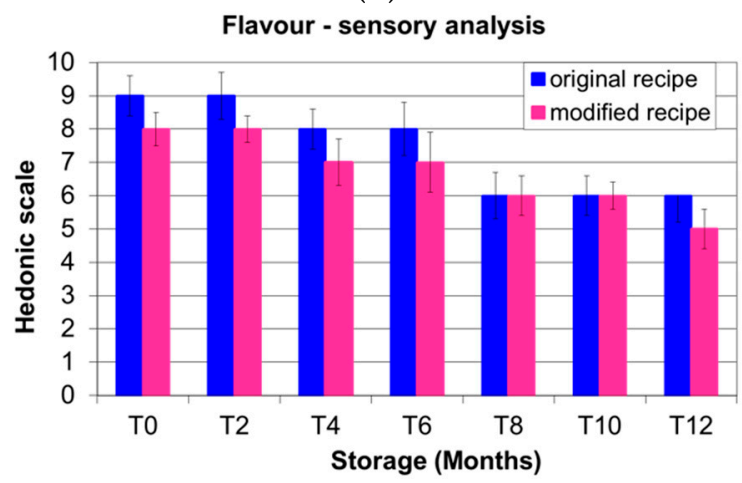

(d)

Figure 3. Cont. 


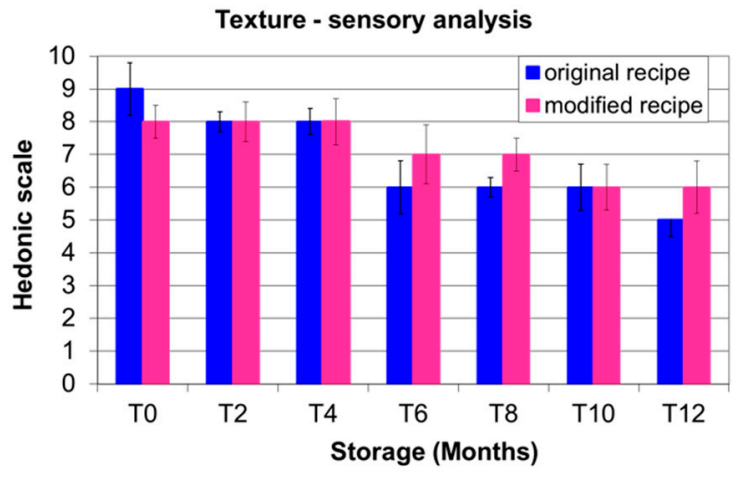

(e)

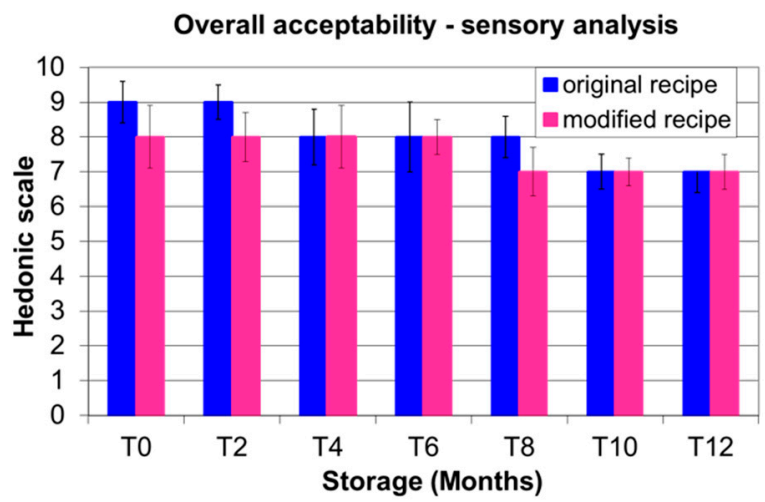

(f)

Figure 3. Sensory analysis of Italian Cantuccini biscuits prepared with the original recipe and the modified recipe during one year's shelf-life: (a) colour; (b) appearance; (c) taste; (d) flavour; (e) texture; (f) overall acceptability.

OR Cantuccini obtained the highest scores until $\mathrm{T} 4$ and were equally evaluated from $\mathrm{T} 6$ to T10, whereas at T12 the biscuits prepared with EVOO were preferred (Figure 3b).

The taste and flavour of OR Cantuccini were preferred in the first period of storage, although the panelists gave the same scores at T10 and T12 for taste and the same scores at T8 and T10 for flavour, with a preference for the flavour of OR at T12 (Figure 3c,d). The texture was more appreciated in $\mathrm{OR}$ at $\mathrm{T} 0$, after which the panelists preferred the biscuits prepared with the modified recipe (Figure 3e). Regarding overall acceptability, OR biscuits obtained the highest scores at T0, T2 and T8, whereas the same scores were obtained for $\mathrm{OR}$ and MR for the remaining sampling dates (Figure 3f).

We can speculate that the EVOO in the recipe preserved or extended the Cantuccini shelf-life and consequently the sensory properties. Our observations are in agreement with the findings of other authors, who studied the addition of phenolic extracts from olive leaves and olive mill wastewater to gluten-free breadsticks and found an amelioration in the physical-chemical-sensory properties of these bakery products [47].

Sensory properties and shelf-life were found to be related. In a study conducted on the shelf-lives of 3-month-packaged biscuits, other authors found no substantial variation in the first 2 months of storage and only slightly decreased scores for certain sensory attributes (texture, taste, flavour) after 3 months of storage [35].

\subsection{Fat}

\subsubsection{Colour of Fat}

The colour values for Cantuccini fats are depicted in the Table 5. Luminance $\left(L^{*}\right)$ was always highest in the OR Cantuccini, which showed a constant and significant decrease $(p<0.05)$ from 25.51 (T0) to 23.90 (T12). The same decreasing behaviour was measured in MR Cantuccini from 24.80 (T0) to 21.69 (T12) $(p<0.001)$. These values describe a browning of the fat during storage in both recipes.

The fat colour of MR Cantuccini produced the highest $a^{*}$ values for the first 8 months and at the same time an increasing trend from 0.50 (T0) to 0.87 (T12) and a $74 \%$ increase in red colouring after 12 months $(p<0.001)$, whereas the $a^{*}$ values in the fat of OR Cantuccini increased from 0.45 (T0) to 1.19 (T12) with an increase of $164 \%(p<0.001)$. The $a^{*}$ values showed constant reddening of the fat for both recipes during the shelf-life. The $b^{*}$ values of OR Cantuccini moved between 3.26 (T0) and 5.08 (T12), with yellowing of the fat during the 12 month storage period, whereas the fat extracted from MR Cantuccini showed an inverse and decreasing behaviour from 5.07 (To) to 4.28 (T12) with a tendency toward blue colouring. 
Table 5. Colour of fat samples from Cantuccini biscuits made from the original recipe (OR; $50 \%$ cow's butter $/ 50 \%$ margarine) and modified recipe (MR; 70\% EVOO/30\% cow's butter). One-way ANOVA, means \pm SD (of six replicates) in the same row followed by a different letter are significantly different according to Tukey's test; ${ }^{*} p<0.05 ;{ }^{* * *} p<0.001$.

\begin{tabular}{lcccccccc}
\hline & T0 & T2 & T4 & T6 & T8 & T10 & T12 & Sign. \\
\hline$L^{*}$ OR & $25.51 \mathrm{a}$ & $25.04 \mathrm{a}$ & $25.44 \mathrm{a}$ & $24.79 \mathrm{a}$ & $24.88 \mathrm{a}$ & $24.17 \mathrm{~b}$ & $23.90 \mathrm{~b}$ & $*$ \\
$L^{*} \mathrm{MR}$ & $24.80 \mathrm{a}$ & $24.24 \mathrm{a}$ & $23.44 \mathrm{a}$ & $22.80 \mathrm{~b}$ & $22.32 \mathrm{~b}$ & $21.66 \mathrm{~b}$ & $21.69 \mathrm{~b}$ & $* * *$ \\
\hline$a^{*}$ OR & $0.45 \mathrm{~d}$ & $0.50 \mathrm{~d}$ & $0.60 \mathrm{c}$ & $0.65 \mathrm{c}$ & $0.66 \mathrm{c}$ & $0.94 \mathrm{~b}$ & $1.19 \mathrm{a}$ & $* * *$ \\
$a^{*} \mathrm{MR}$ & $0.50 \mathrm{~d}$ & $0.54 \mathrm{~d}$ & $0.71 \mathrm{c}$ & $0.76 \mathrm{bc}$ & $0.76 \mathrm{bc}$ & $0.80 \mathrm{ab}$ & $0.87 \mathrm{a}$ & $* * *$ \\
\hline$b^{*} \mathrm{OR}$ & $5.08 \mathrm{a}$ & $4.95 \mathrm{~b}$ & $3.90 \mathrm{c}$ & $3.95 \mathrm{c}$ & $3.64 \mathrm{~d}$ & $3.39 \mathrm{e}$ & $3.26 \mathrm{e}$ & $* * *$ \\
$b^{*} \mathrm{MR}$ & $5.07 \mathrm{a}$ & $4.89 \mathrm{~b}$ & $4.62 \mathrm{c}$ & $4.65 \mathrm{c}$ & $4.55 \mathrm{~d}$ & $4.31 \mathrm{e}$ & $4.28 \mathrm{e}$ & $* * *$ \\
\hline Chroma OR & $5.10 \mathrm{a}$ & $4.98 \mathrm{ab}$ & $3.95 \mathrm{c}$ & $4.00 \mathrm{c}$ & $3.70 \mathrm{~d}$ & $3.52 \mathrm{~d}$ & $3.47 \mathrm{e}$ & $* * *$ \\
Chroma MR & $5.09 \mathrm{a}$ & $4.92 \mathrm{~b}$ & $4.67 \mathrm{c}$ & $4.71 \mathrm{c}$ & $4.61 \mathrm{~cd}$ & $4.38 \mathrm{e}$ & $4.37 \mathrm{e}$ & $* * *$ \\
\hline
\end{tabular}

Chroma testing is applied to evaluate the degree of difference of a hue in comparison to a grey with the same lightness. The higher the chroma values, the higher the colour intensity of the samples as perceived by humans [24]. In both recipes, the chroma values decreased significantly during the storage year, in particular in the fat of OR Cantuccini.

Other studies have shown the influence of fat on colouring. Goubgou et al. [48] studied sorghum cookies prepared with refined cottonseed oil, refined palm oil and crude palm oil ( $16 \%, 20 \%$ and $24 \%$ in the recipe, respectively), and found browning on all cookies, with yellowing on cookies produced with red palm oil. In addition, they found that the higher the fat content in the recipe, the higher the browning intensity. In a study conducted on 3D-printed cookies, the influence of fat (butter and olive oil) on the cookies' colour was assessed. The authors found that the colour parameter $b^{*}$ and chroma values were significantly influenced by the interaction between flour and fat $(p<0.05)$, with the most intensive sample being prepared with oats and olive oil [49].

\subsubsection{Free Acidity}

Acidity showed a very high and significant variation during storage $(p<0.01)$ in fat extracted from both OR and MR Cantuccini, with a tendency to increase with storage (Figure 4a). In detail, the acidity of OR fat was $1.61 \%$ in the control (T0) and $2.27 \%$ at T12 (47.20\% increase), whereas the acidity of MR fat was $1.02 \%$ in the control (T0) and $1.35 \%$ at T12 (32.35\% increase). The acidity of MR fat was lower than that of OR at all studied storage dates, in particular the difference as an absolute value in the control was $0.59 \%$, whereas after 12 months' storage it was $1.12 \%$. This means that EVOO in the recipe reduced free fatty acid formation and maintained lower acidity. The lowest free acidity occurring in the fat of MR Cantuccini may have been due having to the lowest RH; in fact, moisture facilitates the hydrolytic degradation of fats.

The free acidity levels of pure fats and oils used in this study before being added to the dough were $0.22 \%$ for margarine, $0.60 \%$ for cow's butter and $0.70 \%$ for EVOO.

Daglioglu et al. [50] studied the free acidity variation in the fats extracted using $n$ hexane from 8 different bakery products, and in all cases found significant and constant acidity increases during a 12 month storage period, with the highest value found in wafers $(1.20 \%)$. Similarly, free acidity increases were found in six different biscuits prepared with six different cereals and stored with two different packaging materials and for three months [51]. 


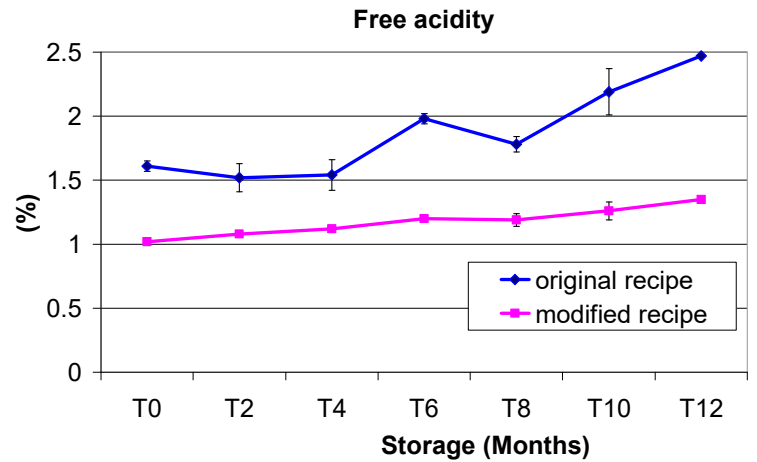

(a)

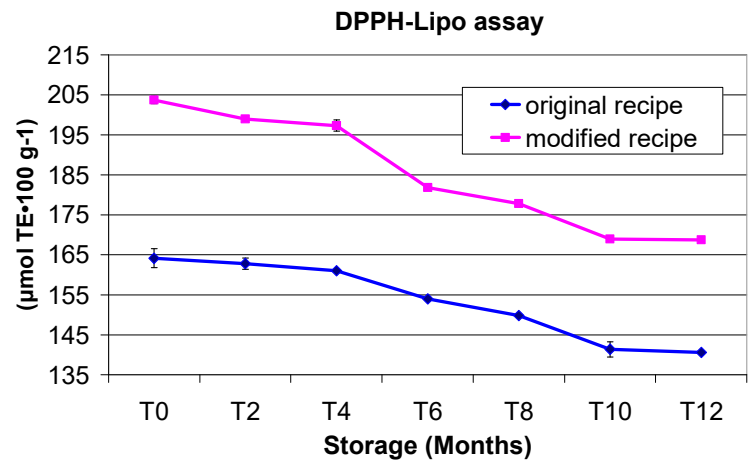

(b)

Figure 4. (a) Free acidity levels of fat samples extracted from Italian Cantuccini biscuits prepared with the original recipe and the modified recipe during one year's shelf-life. (b) DPPH-Lipo assay results for fat samples extracted from Italian Cantuccini biscuits prepared with the original recipe and the modified recipe during one year's shelf-life.

\subsubsection{DPPH Assay}

The DPPH assay is commonly applied to many matrices to test their antioxidant capacity [52-54].

The antioxidant activity was almost always highest in the lipid fraction of the fat obtained from the MR Cantuccini. At T0 (control), the DPPH value was 203.74 ( $\mu \mathrm{mol}$ TE. $100 \mathrm{~g}^{-1}$ fat) in fat from MR and 164.15 ( $\mu \mathrm{mol} \mathrm{TE} \cdot 100 \mathrm{~g}^{-1}$ fat) in fat from OR (i.e., $24.12 \%$ more than in the recipe containing EVOO). During 12 months' storage, a continuous reduction was found in the antioxidant activity measured with the DPPH assay (Figure 3b). At T6, the antioxidant activity levels were 181.83 and $153.97 \mu \mathrm{mol} \mathrm{TE} \cdot 100 \mathrm{~g}^{-1}$ fat, respectively, for MR and OR (18.01\% more than in the recipe containing EVOO). After 12 months' storage, the antioxidant activity levels were 168.75 (MR) and 140.58 (OR) $\mu \mathrm{mol} \mathrm{TE} \cdot 100 \mathrm{~g}^{-1}$ fat, respectively, i.e., a decrease of $20.73 \%$ from T0 to $\mathrm{T} 12$ for the MR and a decrease of 16.77 in the same period for the OR (Figure $4 \mathrm{~b}$ ). These data demonstrated that the antioxidant activity was positively influenced by the EVOO included in the MR during 12 months storage. Our findings agree with Omran et al. [55], who studied biscuits prepared with wheat flour and with different percentages of defatted and non-defatted flaxseed flour, observing a decreasing trend in the DPPH assay value over 3 months' storage.

\subsubsection{Spectrophotometric Indices in the UV}

The K232 value indicates the presence of dienes conjugates. The conjugated structure formed in fatty acids is important because it is more prone to oxidative reactions compared to the isolated structure and causes drying reactions in oil in the presence of oxygen. The increase in conjugate-diene formation during oxidative reactions is a very important parameter because it gives information about the state of the oil degradation.

In the studied samples, at T0 the K232 and K268 values were higher in OR fat (2.71 and 2.31 , respectively) than in the MR fat (2.05 and 0.69, respectively). This was due to the high spectrophotometric K232 indices of 2.914 and 2.062, respectively, for cow's butter and margarine as a consequence of the high conjugated diene content. At the same time, the K268 indices were also high for both cow's butter (0.726) and margarine (0.751) in relation to the conjugated trienes.

The tendency found was an increasing trend with time for both the MR fat and OR fat. The K232 value in the OR fat was 3.44 after 12 months' storage (26.94\% more than T0) $(p<0.001)$, whereas the K232 value in the MR fat was 3.22 after 12 months' storage ( $57.08 \%$ more than T0) $(p<0.001)$; this meant that the relative increase was more or less 2 times higher in the fat from the MR, although the absolute values were similar in fats from the OR and MR, especially in the last 4 months of storage (Figure 5a). 


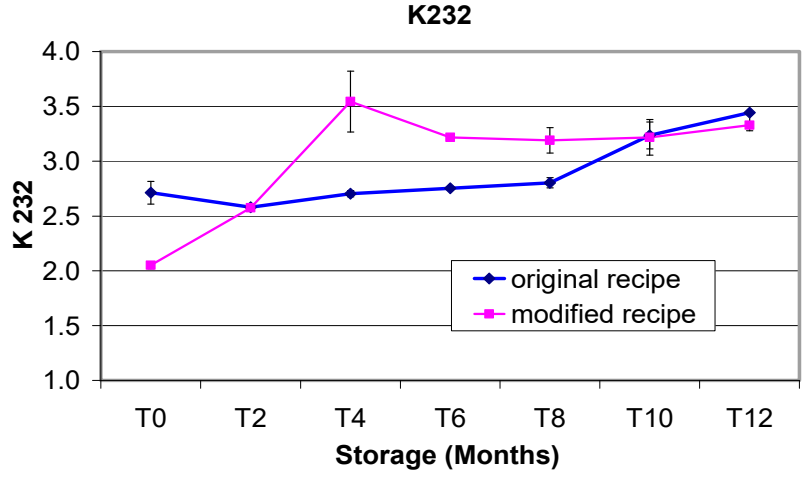

(a)

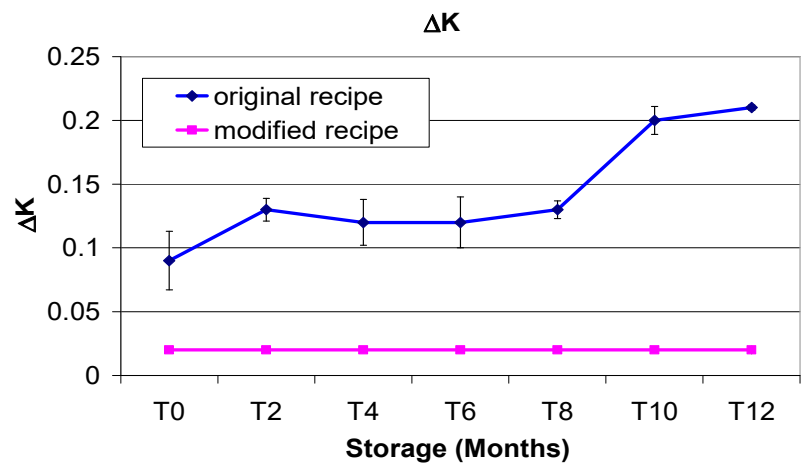

(c)

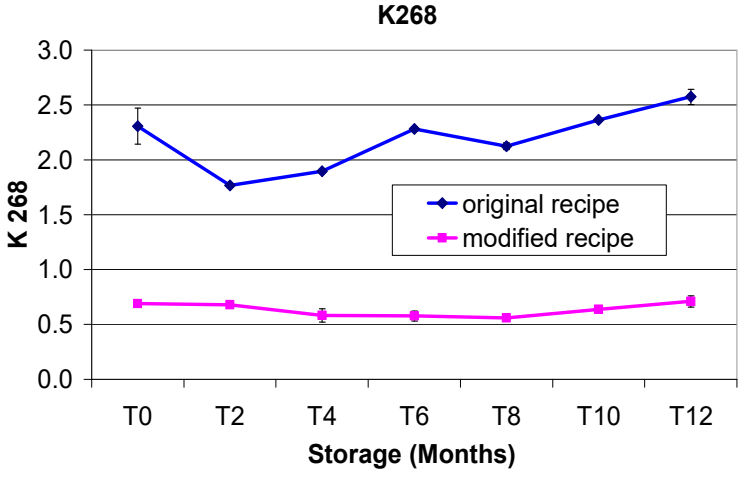

(b)

Figure 5. (a) K232 values for fat samples extracted from Italian Cantuccini biscuits prepared from the original recipe and the modified recipe during one year's shelf-life. (b) K268 values for fat samples extracted from Italian Cantuccini biscuits prepared from the original recipe and the modified recipe during one year's shelf-life; (c) The $\Delta \mathrm{K}$ values for fat samples extracted from Italian Cantuccini biscuits prepared from the original recipe and the modified recipe during one year's shelf-life.

In a study conducted on Turkish margarines during 12 weeks' storage, the K232 values were found to fluctuate in the range of 3.17-9.35 for margarines stored at $4{ }^{\circ} \mathrm{C}$, whereas for margarines stored at $25^{\circ} \mathrm{C}$ the $\mathrm{K} 232$ variation was found to be between 4.45 and 13.03 [56].

The K268 value in the OR fat was 3.22 after 12 months' storage (11.69\% more than T0), whereas the K268 value in the MR fat was 0.64 after 12 months' storage, i.e., only partially different from the T0 value (Figure $5 b$ ).

Additionally, the high K268 indices were due to the fats used in OR Cantuccini, namely 0.751 for cow's butter and 0.726 for margarine, as a consequence of the high conjugated triene content.

Schafer-De Martini Soares et al. [57] studied the K270 values in margarines prepared by enzymatic interesterification and containing palm stearin, palm kernel oil and olive oil. They found absorbance rates varying between 0.5 and 1.3 in relation to the immobilized thermostable lipases used and regardless of whether the analytical determination was conducted prior to or after the interesterification.

The $\Delta \mathrm{K}$ value was higher in fat from $\mathrm{OR}$ than in fat from MR at all sampling points ( 0.09 and 0.02 at T0; 0.12 and 0.02 at T6; 0.21 and 0.02 at T12) (Figure 5c). It is worth noting that the $\Delta \mathrm{K}$ value in fat from OR Cantuccini increased by $133.33 \%$ over 12 months, whereas the $\Delta \mathrm{K}$ value calculated in fat from MR Cantuccini remained the same (0.09) over 12 months' storage (Figure 5c). Caponio et al. [58] studied the evolution of K232 and K268 during 5 months' storage of Taralli (a savoury biscuit) prepared with extra virgin olive oil, olive pomace oil and refined palm oil, and found that extra virgin olive oil always showed the lowest values for both indices. This confirms our results regarding K268, for which extra virgin olive oil showed a reduction in the formation of the secondary products of oxidation. 


\subsubsection{FAMEs}

The Trade Standard applied to olive oil by the International Olive Council [59] and the European Regulation on olive oil [5] describes the fatty acid composition of olive oil as ranging between $\mathrm{C} 14: 0$ and $\mathrm{C} 24: 0$. The fatty acids ranging between $\mathrm{C} 4: 0$ and $\mathrm{C} 12: 0$ have to be ascribed to cow's butter [60,61]. For this reason, the C4:0 to C12:0 fatty acids were found in the highest quantities in the OR Cantuccini.

The FAME composition of the OR Cantuccini showed $36.21-38.60 \%$ of SFAs (Table 6), whereas the modified recipe contained $14.70-19.29 \%$ SFAs (Table 7). Reciprocally, the FAME composition of the original recipe showed $61.40-63.79 \%$ UFAs, whereas the modified recipe showed $80.71-85.30 \%$ UFAs. This difference was due to both the absence of margarine and the 50 to $30 \%$ reduction in cow's butter in the modified recipe with the addition of $70 \%$ EVO. Margarine is a hydrogenated fat, and the type used in this work was found to contain $44.75 \%$ SFAs and 55.25\% UFAs. Each SFA has different effects on the plasma concentrations of the various fractions of lipoproteins bound to cholesterol. For example, C12:0, C14:0 and C16:0 increase the level of cholesterol linked to high-density lipoproteins; for this reason, in recipe for bakery products, it is useful to reduce the C12:0, C14:0 and C16:0 contents [62]. Replacing SFAs (C12:0-C16:0) with MUFAs leads to reductions in LDL-bound cholesterol, as well as in the total cholesterol/HDL cholesterol ratio, and improves the insulin sensitivity [62]. The total levels of C12:0, C14:0 and C16:0 varied from $28.87-32.18 \%$ (OR) to $10.57-11.74 \%$ (MR), with reductions ranging from $2.73-$ to 2.74 -fold. The use of olive oil in the Cantuccini recipe increased the C18:1 content from $37.55-40.65 \%$ (OR) to $59.02-63.18 \%$ (MR), i.e., from 1.57 to 1.55 times more, with an evident health benefit for the consumer. Oleic acid (C18:1), the most common MUFA in olive oil, was found to be an antiapoptotic and anti-inflammatory agent via regulation of cyclooxygenase-2 (COX-2) and inducible nitric oxide synthase (iNOS) through the activation of nuclear factorkappa B (NF- $\mathrm{kB})$, resulting in the activation of downstream inflammatory mediators [63]. High significant differences were found between the fat contents in the two recipes during Cantuccini storage. The $\Sigma$ SFA values varied between $38.60 \%$ (T0) and $36.99 \%$ (T12) in OR and between $19.29 \%$ (T0) and $15.84 \%$ (T12) in MR, with the minimum content being observed at T4 (14.70\%). The $\Sigma$ MUFA values varied from $39.16 \%$ (T0) to $42.81 \%$ (T12) in OR and from $62.35 \%$ (T0) and $64.71 \%$ (T12) in MR, with the maximum content being observed at $\mathrm{T} 4(66.53 \%)$. C18:1 accounted for $37.55 \%$ at $\mathrm{T} 0$ and $40.65 \%$ at $\mathrm{T} 12$ in the OR, whereas it accounted for $59.02 \%$ at T0 and $61.12 \%$ at T12 in the MR. In both recipes, both

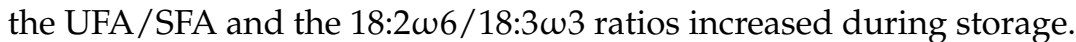


Table 6. Fatty acid methyl esters found in the original recipe Cantuccini. One-way ANOVA, means \pm SD (of six replicates) in the same column followed by a different letter are significantly different according to Tukey's test; ${ }^{* * *} p<0.001 ;{ }^{* *} p<0.01 ;{ }^{*} p<0.05$; n.s., not significant.

\begin{tabular}{|c|c|c|c|c|c|c|c|c|c|c|c|c|c|c|c|c|c|c|c|}
\hline \multicolumn{20}{|c|}{ (a) } \\
\hline & C4:0 & C6:0 & C8:0 & C10:0 & C12:0 & C14:0 & C16:0 & $\mathrm{C} 16: 1$ & C17:0 & C17:1 & C18:0 & C18:1 & C18:1w7 & C18:2 & C18:2TT & C18:2CT & C18:2TC & C18:3w3 & C18:3w6 \\
\hline T0 & $1.54 \mathrm{e}$ & $0.17 \mathrm{a}$ & $0.01 \mathrm{a}$ & $0.01 \mathrm{a}$ & $0.14 \mathrm{a}$ & $0.70 \mathrm{a}$ & $31.34 \mathrm{a}$ & $0.43 \mathrm{ab}$ & $0.09 \mathrm{ab}$ & $0.04 \mathrm{~b}$ & $4.12 \mathrm{a}$ & $37.55 \mathrm{~d}$ & $0.90 \mathrm{~b}$ & 21.27 a & $0.21 \mathrm{~b}$ & $0.19 \mathrm{~b}$ & $0.01 \mathrm{a}$ & $0.53 \mathrm{a}$ & $0.03 \mathrm{a}$ \\
\hline T2 & $1.93 \mathrm{c}$ & $0.11 \mathrm{bc}$ & $0.01 \mathrm{a}$ & $0.01 \mathrm{a}$ & $0.11 \mathrm{~b}$ & $0.60 \mathrm{~b}$ & $28.98 \mathrm{bc}$ & $0.44 \mathrm{ab}$ & $0.09 \mathrm{abc}$ & $0.04 \mathrm{ab}$ & $3.90 \mathrm{a}$ & $40.12 \mathrm{ab}$ & $1.13 \mathrm{ab}$ & $20.96 \mathrm{a}$ & $0.19 \mathrm{~b}$ & $0.18 \mathrm{bc}$ & tr & $0.47 \mathrm{~b}$ & $0.01 \mathrm{a}$ \\
\hline T4 & $3.15 \mathrm{a}$ & $0.12 \mathrm{~b}$ & $0.01 \mathrm{a}$ & $0.01 \mathrm{a}$ & $0.10 \mathrm{~b}$ & $0.58 \mathrm{~b}$ & $28.19 \mathrm{c}$ & $0.41 \mathrm{~b}$ & $0.10 \mathrm{a}$ & $0.04 \mathrm{~b}$ & $5.10 \mathrm{a}$ & $40.07 \mathrm{~b}$ & $1.42 \mathrm{a}$ & $19.18 \mathrm{~d}$ & $0.18 \mathrm{~b}$ & $0.15 \mathrm{c}$ & tr & $0.43 \mathrm{bc}$ & $0.02 \mathrm{a}$ \\
\hline $\begin{array}{l}\mathrm{T} 6 \\
\mathrm{~T} 8\end{array}$ & $\begin{array}{l}2.45 \mathrm{~b} \\
1.6 \mathrm{~d}\end{array}$ & $\begin{array}{l}0.13 \mathrm{~b} \\
0.12 \mathrm{~b}\end{array}$ & $0.01 \mathrm{a}$ & $\begin{array}{l}0.01 \mathrm{a} \\
0.01 \mathrm{a}\end{array}$ & $\begin{array}{l}0.11 \mathrm{~b} \\
011 \mathrm{~b}\end{array}$ & $0.61 \mathrm{~b}$ & $\begin{array}{l}30.49 \mathrm{ab} \\
3111 \mathrm{a}\end{array}$ & $\begin{array}{l}0.41 \mathrm{~b} \\
043 \mathrm{ab}\end{array}$ & $\begin{array}{l}0.10 \mathrm{a} \\
0.8 \mathrm{c}\end{array}$ & $\begin{array}{l}0.04 \mathrm{ab} \\
0.04 \mathrm{~b}\end{array}$ & $\begin{array}{l}3.89 \mathrm{a} \\
3.95 \mathrm{a}\end{array}$ & $\begin{array}{l}38.66 \mathrm{c} \\
3389 \mathrm{c}\end{array}$ & $\begin{array}{l}1.18 \mathrm{ab} \\
107 \mathrm{ab}\end{array}$ & $\begin{array}{ll}20.34 & \text { abc } \\
2041 & 1 \mathrm{~b}\end{array}$ & $\begin{array}{l}0.20 \mathrm{~b} \\
0.21 \mathrm{~b}\end{array}$ & $\begin{array}{l}0.17 \mathrm{bc} \\
0.15 \mathrm{c}\end{array}$ & $\underset{t r}{0.01 \mathrm{a}}$ & $\begin{array}{l}0.45 \mathrm{~b} \\
0.42 \mathrm{bc}\end{array}$ & $\begin{array}{l}0.03 \mathrm{a} \\
0.02 \mathrm{a}\end{array}$ \\
\hline${ }_{\mathrm{T} 12}^{10}$ & $\begin{array}{l}0.62 \mathrm{f} \\
0.59 \mathrm{f}\end{array}$ & $\begin{array}{l}0.09 \mathrm{~cd} \\
0.08 \mathrm{~d}\end{array}$ & $\begin{array}{l}0.01 \mathrm{a} \\
0.01 \mathrm{a}\end{array}$ & $\begin{array}{l}0.01 \mathrm{a} \\
0.01 \mathrm{a}\end{array}$ & $\begin{array}{l}0.11 \mathrm{~b} \\
0.10 \mathrm{~b}\end{array}$ & $\begin{array}{l}0.58 \mathrm{~b} \\
0.58 \mathrm{~b}\end{array}$ & $\begin{array}{l}31.28 \mathrm{a} \\
31.36 \mathrm{a}\end{array}$ & $\begin{array}{l}0.4 \mathrm{ab} \\
0.46 \mathrm{a}\end{array}$ & $\begin{array}{l}0.08 \mathrm{bc} \\
0.09 \mathrm{ab}\end{array}$ & $\begin{array}{l}0.04 \mathrm{~b} \\
0.05 \mathrm{a}\end{array}$ & $\begin{array}{l}3.86 \mathrm{a} \\
3.76 \mathrm{a} \\
\end{array}$ & $\begin{array}{l}40.56 \mathrm{ab} \\
40.65 \mathrm{a}\end{array}$ & $\begin{array}{l}\begin{array}{l}1.38 \mathrm{a} \\
1.46 \mathrm{a}\end{array} \\
-\end{array}$ & $\begin{array}{l}\text { l9,4.4bcd } \\
19.32 \mathrm{~cd}\end{array}$ & $\begin{array}{l}0.27 \mathrm{a} \\
0.26 \mathrm{a}\end{array}$ & $\begin{array}{l}0.20 \mathrm{ab} \\
0.22 \mathrm{a}\end{array}$ & $\begin{array}{l}\mathrm{tr} \\
\text { tr }\end{array}$ & $\begin{array}{l}0.40 \mathrm{c} \\
0.39 \mathrm{c}\end{array}$ & $\begin{array}{l}0.01 \mathrm{a} \\
0.01 \mathrm{a}\end{array}$ \\
\hline sign. & $* * *$ & $* * *$ & n.s. & n.s. & $* * *$ & $4 * *$ & $* * *$ & $* *$ & $* * *$ & ** & n.s. & $* * *$ & ** & $* * *$ & $* * *$ & $* * *$ & $* * *$ & $* * *$ & * \\
\hline \multicolumn{20}{|c|}{ (b) } \\
\hline & C20:0 & C20:1 & C22:0 & C22:1 & C24:0 & \multicolumn{2}{|c|}{ ESFAs } & \multicolumn{2}{|c|}{ IUFAs } & \multicolumn{2}{|c|}{ EMUFAs } & \multicolumn{2}{|c|}{ EPUFAs } & \multicolumn{2}{|c|}{ UFAs/SFAs } & $18: 2 \omega 6 / 18: 3 \omega 3$ & \multicolumn{3}{|c|}{ C12:0 + C14:0 + C16:0 } \\
\hline T0 & $0.27 \mathrm{a}$ & $0.20 \mathrm{a}$ & $0.13 \mathrm{a}$ & $0.04 \mathrm{ab}$ & $0.08 \mathrm{a}$ & \multicolumn{2}{|c|}{38.60} & \multicolumn{2}{|c|}{$\begin{array}{l}61.40 \mathrm{~d} \\
63.79 \mathrm{a}\end{array}$} & & & \multicolumn{2}{|c|}{$\begin{array}{l}22.25 \mathrm{a} \\
21.80 \mathrm{a}\end{array}$} & \multicolumn{2}{|c|}{$\begin{array}{l}1.59 c \\
1.76 a\end{array}$} & $40.13 \mathrm{c}$ & \multicolumn{3}{|c|}{$32.18 \mathrm{a}$} \\
\hline T4 & $0.27 \mathrm{a} \mathrm{a}$ & $0.19 \mathrm{bc}$ & $0.14 \mathrm{a}$ & $0.06 \mathrm{a}$ & $0.07 \mathrm{a}$ & \multicolumn{2}{|c|}{$\begin{array}{l}37.85 \mathrm{~b} \\
38.26\end{array}$} & \multicolumn{2}{|c|}{$62.15 \mathrm{c}$} & & & \multicolumn{2}{|c|}{$19.96 \mathrm{c}$} & \multicolumn{2}{|c|}{$1.64 \mathrm{c}$} & $45.12 \mathrm{~b}$ & \multicolumn{3}{|c|}{$\begin{array}{l}29.69 \mathrm{~d} \\
28.87 \mathrm{e}\end{array}$} \\
\hline $\begin{array}{l}\text { T6 } \\
\text { Ts }\end{array}$ & $0.27 \mathrm{a}$ & $0.19 \mathrm{ab}$ & $0.12 \mathrm{a}$ & $0.06 \mathrm{a}$ & $0.08 \mathrm{a}$ & \multicolumn{2}{|c|}{$\begin{array}{r}38.26 \mathrm{ab} \\
38.15 \mathrm{ab}\end{array}$} & \multicolumn{2}{|c|}{$\begin{array}{l}61.74 \mathrm{~cd} \\
61585 \mathrm{co}\end{array}$} & & & & & \multicolumn{2}{|c|}{$1.61 \mathrm{c}$} & $45.21 \mathrm{~b}$ & \multicolumn{3}{|c|}{$31.21 \mathrm{c}$} \\
\hline $\begin{array}{l}\text { T8 } \\
\text { T10 }\end{array}$ & $\begin{array}{l}0.27 \mathrm{a} \\
022 \mathrm{~b}\end{array}$ & $\begin{array}{l}0.18 \mathrm{~cd} \\
0.17 \mathrm{~d}\end{array}$ & $\begin{array}{l}0.12 \mathrm{a} \\
011 \mathrm{a}\end{array}$ & $\begin{array}{l}0.04 \mathrm{ab} \\
0.02 \mathrm{~b}\end{array}$ & $\begin{array}{l}0.07 \mathrm{a} \\
0.07 \mathrm{a}\end{array}$ & \multicolumn{2}{|c|}{$\begin{array}{l}38.15 \\
37.09 \mathrm{c}\end{array}$} & \multirow{2}{*}{\multicolumn{2}{|c|}{$\begin{array}{l}61.8 \mathrm{scd} \\
62.91 \mathrm{~b} \\
63.01 \mathrm{~b}\end{array}$}} & & & \multirow{2}{*}{\multicolumn{2}{|c|}{$\begin{array}{l}11.20 \mathrm{ab} \\
20.30 \mathrm{bc} \\
20.20 \mathrm{c}\end{array}$}} & \multirow{2}{*}{\multicolumn{2}{|c|}{$\begin{array}{l}1.62 \mathrm{c} \\
1.70 \mathrm{~b}\end{array}$}} & $\begin{array}{r}49.02 \mathrm{ab} \\
40.04\end{array}$ & \multicolumn{3}{|c|}{$\begin{array}{r}31.83 \mathrm{~b} \\
{ }_{3} 13090\end{array}$} \\
\hline $\begin{array}{l}\text { T110 } \\
\text { T12 }\end{array}$ & $\begin{array}{l}0.24 \mathrm{~b} \\
0.22 \mathrm{c}\end{array}$ & $\begin{array}{l}0.17 \mathrm{~d} \\
0.15 \mathrm{e}\end{array}$ & $\begin{array}{l}0.1 \mathrm{a} a \\
0.10 \mathrm{a}\end{array}$ & $\begin{array}{l}0.02 \mathrm{~b} \\
0.02 \mathrm{~b}\end{array}$ & $\begin{array}{l}0.07 \mathrm{a} a \\
0.08 \mathrm{a}\end{array}$ & \multicolumn{2}{|c|}{$\begin{array}{l}37.09 \mathrm{c} \\
36.99 \mathrm{c}\end{array}$} & & & & & & & & & $\begin{array}{r}49.01 \mathrm{ab} \\
49.96 \mathrm{a}\end{array}$ & & $\begin{array}{l}31.99 \mathrm{~b} \\
32.04 \mathrm{a}\end{array}$ & \\
\hline Sign. & $* * *$ & $x * * *$ & $\begin{array}{l}\text { n.s. } \\
\text { nat }\end{array}$ & n.s. & ${ }_{* * *}$ & & & & & & & & & & & n.s. & & $* * * *$ & \\
\hline
\end{tabular}

Table 7. Fatty acid methyl esters found in the modified recipe Cantuccini. One-way ANOVA, means \pm SD (of six replicates) in the same column followed by a different letter are significantly different according to Tukey's test; ${ }^{* * *} p 0.001$; n.s., not significant.

\begin{tabular}{|c|c|c|c|c|c|c|c|c|c|c|c|c|c|c|c|c|c|c|c|}
\hline \multicolumn{20}{|c|}{ (a) } \\
\hline & C4:0 & C6:0 & C8:0 & C10:0 & C12:0 & C14:0 & C16:0 & C16:1 & C17:0 & C17:1 & C18:0 & C18:1 & C18:1w7 & C18:2 & C18:2TT & C18:2CT & C18:2TC & C18:3w3 & C18:3w6 \\
\hline T0 & $2.92 \mathrm{a}$ & $0.02 \mathrm{a}$ & $0.07 \mathrm{~b}$ & $0.07 \mathrm{~b}$ & $0.45 \mathrm{a}$ & $0.30 \mathrm{a}$ & $10.99 \mathrm{a}$ & $0.94 \mathrm{a}$ & $0.11 \mathrm{ab}$ & $0.17 \mathrm{a}$ & $3.88 \mathrm{a}$ & $59.02 \mathrm{e}$ & $1.95 \mathrm{~b}$ & $17.89 \mathrm{~d}$ & 0.03 & 0.01 & 0.01 & 0.42 & $\operatorname{tr}$ \\
\hline T2 & $2.46 \mathrm{~b}$ & $0.01 \mathrm{~b}$ & $0.65 \mathrm{a}$ & $0.65 \mathrm{a}$ & $0.30 \mathrm{e}$ & $0.29 \mathrm{a}$ & $10.40 \mathrm{~b}$ & $0.89 \mathrm{bc}$ & $0.12 \mathrm{a}$ & $0.18 \mathrm{a}$ & $3.58 \mathrm{~b}$ & $59.34 \mathrm{e}$ & $2.03 \mathrm{~b}$ & $17.96 \mathrm{~cd}$ & 0.02 & 0.01 & 0.01 & 0.40 & $\operatorname{tr}$ \\
\hline $\mathrm{T} 4$ & $0.74 \mathrm{e}$ & $0.01 \mathrm{~b}$ & $0.04 \mathrm{~b}$ & $0.06 \mathrm{c}$ & $0.35 \mathrm{bc}$ & $0.25 \mathrm{bc}$ & $10.41 \mathrm{~b}$ & $0.86 \mathrm{c}$ & $0.11 \mathrm{ab}$ & $0.17 \mathrm{a}$ & $2.31 \mathrm{~d}$ & $63.18 \mathrm{a}$ & $2.06 \mathrm{~b}$ & $18.43 \mathrm{~b}$ & $\operatorname{tr}$ & $\operatorname{tr}$ & $\operatorname{tr}$ & 0.34 & $\operatorname{tr}$ \\
\hline T8 & $0.78 \mathrm{e}$ & $0.01 \mathrm{~b}$ & $0.05 \mathrm{~b}$ & $0.05 \mathrm{c}$ & $0.34 \mathrm{c}$ & $0.28 \mathrm{ab}$ & $10.74 \mathrm{a}$ & $0.90 \mathrm{~b}$ & $0.11 \mathrm{ab}$ & $0.18 \mathrm{a}$ & $3.67 \mathrm{~b}$ & $61.61 \mathrm{c}$ & $2.54 \mathrm{a}$ & $17.55 \mathrm{e}$ & $\operatorname{tr}$ & $\operatorname{tr}$ & $\operatorname{tr}$ & 0.40 & $\operatorname{tr}$ \\
\hline T10 & $1.42 \mathrm{c}$ & $0.01 \mathrm{~b}$ & $0.05 \mathrm{~b}$ & $0.05 c$ & $0.35 \mathrm{bc}$ & $0.25 \mathrm{~b}$ & $9.97 \mathrm{c}$ & $0.81 \mathrm{~d}$ & $0.10 b c$ & $0.17 \mathrm{ab}$ & $3.23 \mathrm{c}$ & $61.11 \mathrm{~d}$ & $2.22 \mathrm{ab}$ & $19.12 \mathrm{a}$ & $\operatorname{tr}$ & $\operatorname{tr}$ & $\operatorname{tr}$ & 0.35 & $\operatorname{tr}$ \\
\hline T12 & $1.42 \mathrm{c}$ & $0.01 \mathrm{~b}$ & $0.05 \mathrm{~b}$ & $0.06 \mathrm{c}$ & $0.35 \mathrm{~b}$ & $0.24 \mathrm{bc}$ & $10.00 \mathrm{c}$ & $0.83 \mathrm{~d}$ & $0.11 \mathrm{ab}$ & $0.16 \mathrm{bc}$ & $3.25 \mathrm{c}$ & $61.12 \mathrm{~d}$ & $2.23 \mathrm{ab}$ & $19.12 \mathrm{a}$ & $\operatorname{tr}$ & $\operatorname{tr}$ & $\operatorname{tr}$ & 0.33 & $\operatorname{tr}$ \\
\hline Sign. & $* * *$ & $* * *$ & $* * *$ & $* * *$ & $* * *$ & $* * *$ & $* * *$ & $* * *$ & $* * *$ & $* * *$ & $* * *$ & $* * *$ & $* * *$ & $* * *$ & n.s. & n.s. & n.s. & $* * *$ & n.s. \\
\hline \multicolumn{20}{|c|}{ (b) } \\
\hline & C20:0 & C20:1 & C22:0 & C22:1 & C24:0 & $\Sigma$ SFAs & \multicolumn{2}{|c|}{$\Sigma$ UFAs } & $\Sigma \mathrm{M}$ & FAs & \multicolumn{2}{|c|}{$\Sigma$ PUFAs } & \multicolumn{2}{|c|}{ UFAs/SFAs } & $18: 2 \omega 6 /$ & $18: 3 \omega 3$ & \multicolumn{3}{|c|}{ C12:0+C14:0+C16:0 } \\
\hline T0 & $0.29 \mathrm{a}$ & $0.21 \mathrm{a}$ & $0.13 \mathrm{a}$ & $0.05 \mathrm{~d}$ & $0.07 \mathrm{a}$ & $19.29 \mathrm{a}$ & \multirow{2}{*}{\multicolumn{2}{|c|}{$\begin{array}{l}80.71 \mathrm{e} \\
81.09 \mathrm{~d}\end{array}$}} & \multicolumn{2}{|c|}{$62.35 \mathrm{f}$} & & & \multicolumn{2}{|c|}{$4.18 \mathrm{~d}$} & \multicolumn{2}{|c|}{$42.60 \mathrm{~d}$} & \multicolumn{3}{|c|}{$11.74 \mathrm{a}$} \\
\hline $\mathrm{T} 2$ & $0.27 \mathrm{abc}$ & $0.19 \mathrm{ab}$ & $0.11 \mathrm{bcd}$ & $0.07 \mathrm{~cd}$ & $0.07 \mathrm{a}$ & $18.91 \mathrm{~b}$ & & & \multirow{2}{*}{\multicolumn{2}{|c|}{$\begin{array}{l}62.69 \mathrm{e} \\
66.53 \mathrm{a}\end{array}$}} & & & \multicolumn{2}{|c|}{$4.29 \mathrm{~d}$} & 45.2 & & \multirow{2}{*}{\multicolumn{3}{|c|}{$11.00 \mathrm{ab}$}} \\
\hline $\mathrm{T} 4$ & $0.27 \mathrm{abc}$ & $0.17 \mathrm{c}$ & $0.10 \mathrm{~cd}$ & $0.08 \mathrm{c}$ & $0.05 \mathrm{bc}$ & $14.70 \mathrm{e}$ & \multicolumn{2}{|c|}{$85.30 \mathrm{a}$} & & & & & & & \multirow{2}{*}{\multicolumn{2}{|c|}{$54.21 \mathrm{~b}$}} & & & \\
\hline T6 & $0.26 \mathrm{bc}$ & $0.17 \mathrm{c}$ & $0.09 \mathrm{~d}$ & $0.12 \mathrm{~b}$ & $0.05 c$ & $15.54 \mathrm{~d}$ & \multirow{2}{*}{\multicolumn{2}{|c|}{$\begin{array}{l}84.46 \mathrm{~b} \\
83.49 \mathrm{e}\end{array}$}} & \multicolumn{2}{|c|}{$65.90 \mathrm{~b}$} & & & \multicolumn{2}{|c|}{$\begin{array}{l}5.80 \mathrm{a} \\
5.43 \mathrm{~b}\end{array}$} & & & \multicolumn{3}{|c|}{$\begin{array}{l}11.00 \mathrm{ab} \\
10.57 \mathrm{c}\end{array}$} \\
\hline T8 & $0.29 \mathrm{ab}$ & $0.19 \mathrm{ab}$ & $0.12 \mathrm{ab}$ & $0.11 \mathrm{~b}$ & $0.06 \mathrm{ab}$ & $16.51 \mathrm{c}$ & & & \multirow{2}{*}{\multicolumn{2}{|c|}{$\begin{array}{l}65.54 \mathrm{c} \\
64.69 \mathrm{~d}\end{array}$}} & & & \multirow{2}{*}{\multicolumn{2}{|c|}{$\begin{array}{l}5.06 \mathrm{c} \\
5.31 \mathrm{~b}\end{array}$}} & 43.5 & & \multicolumn{3}{|c|}{$11.36 \mathrm{a}$} \\
\hline T10 & $0.25 \mathrm{c}$ & $0.20 \mathrm{ab}$ & $0.10 \mathrm{~cd}$ & $0.18 \mathrm{a}$ & $0.06 \mathrm{abc}$ & $15.84 \mathrm{~d}$ & \multicolumn{2}{|c|}{$84.16 \mathrm{~b}$} & & & & & \multirow{2}{*}{\multicolumn{2}{|c|}{$5.31 \mathrm{~b}$}} & 55.1 & & \multicolumn{3}{|c|}{$10.57 \mathrm{c}$} \\
\hline T12 & $0.26 \mathrm{bc}$ & $0.19 \mathrm{bc}$ & $0.12 \mathrm{abc}$ & $0.19 \mathrm{a}$ & $0.05 \mathrm{bc}$ & $15.84 \mathrm{~d}$ & \multicolumn{2}{|c|}{$84.16 \mathrm{~b}$} & \multicolumn{2}{|c|}{$64.71 \mathrm{~d}$} & & & & & 58.5 & 4 a & & $10.57 \mathrm{c}$ & \\
\hline Sign. & $* * *$ & $* * *$ & $* * *$ & $* * *$ & $* * *$ & $* * *$ & \multicolumn{2}{|c|}{$* * *$} & & & & & * & & *** & & & $* * *$ & \\
\hline
\end{tabular}


The changes in fatty acid composition were related to alterations during storage, which were found to be due to the initial fat content, initial water content and storage duration [64]. At the same time, the number and position of double bonds and the storage conditions affect the rate of oxidation $[65,66]$.

Culetu et al. [67] found different fatty acid behaviour during storage in oat-based gluten-free cookies prepared with different fats, such as butter, margarine, lard, palm oil refined palm oil and hydrogenated palm oil. They found a decreasing trend for SFAs for lard and in refined palm oil in stearin cookies, consistent with our SFA results, while at the same time they found a decreasing trend for MUFAs, with the exception of the hydrogenated palm oil cookies, in substantial agreement with our findings.

\section{Conclusions}

The complete replacement of margarine and the partial replacement of butter with extra virgin olive oil in the original Cantuccini biscuit recipe led to improvements in water activity, relative humidity, hardness, K270 values, DPPH assay results and acidity, whereas worse results were found with regard to $\mathrm{K} 232$ and $\Delta \mathrm{K}$ values. This means that the use of extra virgin olive oil in the recipe, in many cases studied in this work, improved the physical and chemical properties of biscuits but worsened the parameters related to the secondary products of oxidation (K270). The Cantuccini biscuit colour was instrumentally evaluated and found to be strictly related to both fats and EVOO and to the length of storage. The fatty acid methyl ester compositions varied dramatically and the use of EVOO increased the unsaturated fatty acid content, in particular monounsaturated fatty acids, with oleic acid being the prevailing compound. The sensory analysis showed an expected worsening of the biscuit quality but good acceptability of Cantuccini prepared with 70\% EVOO. Extra virgin olive oil can be applied to prepare functional products that maintain the physical-chemical-sensory properties of Cantuccini.

Author Contributions: Conceptualization, A.M.G. and M.P.; methodology, A.M.G., M.C. (Manuela Caracciolo), C.Z. and M.C. (Marco Capocasale); software, A.M.G., M.C. (Manuela Caracciolo), C.Z. and M.C. (Marco Capocasale); validation, A.M.G., M.C. (Manuela Caracciolo), C.Z. and M.C. (Marco Capocasale); formal analysis, M.C. (Manuela Caracciolo), C.Z., M.C. (Marco Capocasale) and A.M.G.; investigation A.M.G., M.C. (Manuela Caracciolo), C.Z. and M.C. (Marco Capocasale); resources, M.P. and A.M.G.; data curation A.M.G., M.C. (Manuela Caracciolo), C.Z. and M.C. (Marco Capocasale); writing-original draft preparation, A.M.G.; writing—review and editing, A.M.G. and M.P.; visualization, A.M.G.; supervision, A.M.G. and M.P.; project administration, A.M.G. and M.P.; funding acquisition, M.P. and A.M.G. All authors have read and agreed to the published version of the manuscript.

Funding: This research was funded by the PON03PE_00090_1 fund Process and Product Innovations in Baked Products and Confectionary Food Chains.

Institutional Review Board Statement: Not available.

Informed Consent Statement: Not available.

Data Availability Statement: Not available.

Acknowledgments: This work was conducted within the ambit of the 3 year PhD course (XXXI cycle) of Manuela Caracciolo, namely the PhD in Sciences, Technologies and Biotechnologies for Sustainability. The title of the PhD thesis is Shelf-Life of Bakery Products made with Monocultivar Extra Virgin Olive Oil from Calabria (South Italy): Lipid Matrix Oxidation.

Conflicts of Interest: The authors declare no conflict of interest.

\section{References}

1. Mondorintelligence. 2021. Available online: https://www.mordorintelligence.com/industry-reports/biscuits-market (accessed on 5 July 2021).

2. EU 2016. Available online: https:// eur-lex.europa.eu/legal-content/IT/TXT/PDF/?uri=OJ:JOL_2016_017_R_0003\&from=it (accessed on 20 October 2021). 
3. Disciplinare di Produzione. 2016. Available online: http://www.dop-igp.eu/flex/FixedPages/Common/SchedaDenominazione. $\mathrm{php} / \mathrm{L} / \mathrm{IT} / \mathrm{ID} / 277$ /BL/aHR0cDovL3d3dy5kb3AtaWdwLmV1L2ZsZXgvRml4ZWRQYWdlcy9Db21tb24vRWxlbmNvRGVub2 1pbmF6aW9uaS5waHA \{\}cD0xJmM9JmQ9LTEmdD0tMSZycD1hJTNBMiUzQSU3QnMlM0ExJTNBJTIyciUyMiUzQmklM0 EtMSUzQnMlM0ExJTNBJTIycCUyMiUzQnMlM0ExJTNBJTIyJTJBJTIyJTNCJTdE (accessed on 5 November 2021).

4. Avgerinos, N.A.; Neofytou, P. Mathematical Modelling and Simulation of Atherosclerosis Formation and Progress: A Review. Ann. Biomed. Eng. 2019, 47, 1764-1785. [CrossRef]

5. CONSLEG (2016). Consolidated Text, 01991R2568-EN-04.12.2016-031.005 on The: Characteristics of Olive Oil and Olive-Residue oil and on the relevant methods of analysis, Annexes II, IX, X-A. Available online: https://www.ecolex.org/ details / legislation/commission-regulation-eec-no-256891-on-the-characteristics-of-olive-oil-and-olive-residue-oil-and-onthe-relevant-methods-of-analysis-lex-faoc040621/ (accessed on 30 December 2021).

6. Sánchez-Rodríguez, L.; Kranjac, M.; Marijanović, Z.; Jerković, I.; Corell, M.; Moriana, A.; Carbonell-Barrachina, Á.A.; Sendra, E.; Hernández, F. Quality Attributes and Fatty Acid, Volatile and Sensory Profiles of Arbequina" hydroSOStainable Olive Oil. Molecules 2019, 24, 2148. [CrossRef] [PubMed]

7. Squeo, G.; Silletti, R.; Mangini, G.; Summo, C.; Caponio, F. The Potential of Apulian Olive Biodiversity: The case of Oliva Rossa virgin olive oil. Foods 2021, 10, 369. [CrossRef]

8. Cerretani, L.; Bendini, A.; Del Caro, A.; Piga, A.; Vacca, V.; Caboni, M.F.; GallinaToschi, T. Preliminary characterisation of virgin olive oils obtained from different cultivars in Sardinia. Eur. Food Res. Technol. 2006, 222, 354-361. [CrossRef]

9. Conte, P.; Squeo, G.; Difonzo, G.; Caponio, F.; Fadda, C.; Del Caro, A.; Urgeghe, P.P.; Montanari, L.; Montinaro, A.; Piga, A. Change in quality during ripening of olive fruits and related oils extracted from three minor autochthonous Sardinian cultivars. Emir. J. Food Agric. 2019, 31, 196-205. [CrossRef]

10. Ismea. 2019. Available online: https://www.google.it/search?source=hp\&ei=qg7qXf7oJ46ZsAfdur3IAQ\&q=produzione+olio+

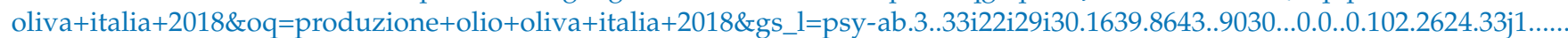
0...1..gws-wiz....0..0i131j0j0i22i30.WAM3r8Uwclw\&ved=0ahUKEwj-5a3yyqDmAhWODOwKHV1dDxkQ4dUDCAc\&uact=5 (accessed on 22 October 2021).

11. Faubion, J.M.; Hoseney, R.C. The viscoelastic properties of wheat flour dough. In Dough Rheology and Baked Product Texture; Faridi, H., Faubion, J.M., Eds.; Van Nostrand Reinhold: New York, NY, USA, 1990.

12. Stauffer, C.E. Fats and oils in bakery products. Cereal Foods World 1998, 43, 120-126.

13. Cauvain, S.P. Breadmaking Processes in Technology of Breadmaking. Cauvain, S.P., Young, L.S., Eds.; Blackie Academic and Professional: London, UK, 1998; pp. 18-44.

14. Jill, I. How Do Different Fats Affect Baking? Published online on 20 December 1999. Available online: http://www.madsci.org/ posts/archives/1999-12/946517625.Ch.r.html (accessed on 15 December 2021).

15. Stauffer, C.E. Fats and Oils in Bakery Product; Wiley Online Library: New York, NY, USA, 2005. [CrossRef]

16. Cauvain, S.P.; Young, L.S. Bakery Food Manufacture and Quality: Water Control and Effects, 2nd ed.; Wiley-Blackwell: Hoboken, NJ, USA; John Wiley \& Sons, Ltd.: Hoboken, NJ, USA; BakeTran, High Wycombe: Buckinghamshire, UK, 2008.

17. Brooker, B. The Role of Fat in Biscuits: Strategy for Fat Reducing Products; Woodhead Publishers: Cambridge, UK, 1998; pp. 127-168.

18. Pasqualone, A.; Bianco, A.M.; Paradiso, V.M. Production trials to improve the nutritional quality of biscuits and to enrich them with natural anthocyanins. CyTA J. Food 2013, 11, 301-308. [CrossRef]

19. Giarnetti, M.; Paradiso, V.M.; Caponio, F.; Summo, C.; Pasqualone, A. Fat replacement in shortbread cookies using an emulsion filled gel based on inulin and extra virgin olive oil. LWT Food Sci. Technol. 2015, 63, 339-345. [CrossRef]

20. FDA. U.S. Food and Drug Administration, Chapter Number 39. 1984. Available online: https://www.fda.gov/inspectionscompliance-enforcement-and-criminal-investigations/inspection-technical-guides/water-activity-aw-foods (accessed on 22 July 2021).

21. ISO 662:1998. Animal and Vegetable Fats and Oils—Determination of Moisture and Volatile Matter Content; ISO: Geneva, Switzerland, 1998.

22. International Standard ISO. ISO 8589:1988 Sensory Analysis—General Guidance for the Design of Test Rooms, 1st ed.; International Standard ISO: Geneva, Switzerland, 1988.

23. Giuffrè, A.M.; Capocasale, M. Policosanol in Tomato Seed Oil (Solanum lycopersicum L.): The effect of cultivar. J. Oleo Sci. 2015, 64, 625-631. [CrossRef]

24. Pathare, P.B.; Opara, U.L.; Al-Julanda Al-Sai, F. Colour measurement and analysis in fresh and processed foods: A Review. Food Bioprocess. Technol. 2013, 6, 36-60. [CrossRef]

25. Kalantzakis, G.; Blekas, G.; Pegklidou, K.; Boskou, D. Stability and radical-scavenging activity of heated olive oil and other vegetable oils. Eur. J. Lipid Sci. Technol. 2006, 108, 329-335. [CrossRef]

26. Louadj, L.; Giuffrè, A.M. Analytical characteristics of olive oil produced with three different processes in Algeria. Riv. Ital. Sostanze Gr. 2010, 87, 186-195.

27. Tepper, B.J. Effects of a slight color variation on consumer acceptance of orange juice. J. Sens. Stud. 1993, 8, 145-154. [CrossRef]

28. Dias, N.A.A.; Lara, S.B.; Soares Miranda, L.; Pires, I.S.C.; Christiano Vieira Pires, C.V.; Halboth, N.V. Influence of color on acceptance and identification of flavor of foods by adults. Ciênc. Tecnol. Aliment. Campinas 2012, 32, 296-301. [CrossRef]

29. Spence, C. On the psychological impact of food colour. Flavour 2015, 4, 21. [CrossRef] 
30. Bajaj, S.; Urooj, A. Effect of incorporation of mint on texture, colour and sensory parameters of biscuits. Int. J. Food Prop. 2006, 9 , 691-700. [CrossRef]

31. Jan, K.N.; Panesar, P.S.; Singh, S. Optimization of antioxidant activity, textural and sensory characteristics of gluten-free cookies made from whole indian quinoa flour. LWT Food Sci. Technol. 2018, 93, 573-582. [CrossRef]

32. de Morais, M.P.; Caliari, M.; Nabshima, E.H.; Jaqueline Eduarda Rodrigues Batista, J.E.; Hidalgo-Campos, M.R.; Soares Junior, M. Storage stability of sweet biscuit elaborated with recovered potato starch from effluent of fries industry. Food Sci. Technol. Campinas 2018, 38, 216-222. [CrossRef]

33. Robertson, G.L. Modified Atmosphere Packaging. In Food Packaging_Principles and Practice, 2nd ed.; CRC Press: Boca Raton, FL, USA, 2006.

34. Balestra, F.; Verardo, V.; Tappi, S.; Caboni, M.F.; Dalla Rosa, M.; Romani, S. Chemical and physical changes during storage of differently packed biscuits formulated with sunflower oil. J. Food Sci. Technol. 2019, 56, 4714-4721. [CrossRef]

35. Chowdhury, K.; Khan, S.; Karim, R.; Obaid, M.; Hasan, G.M.M.A. Quality and shelf-life evaluation of packaged biscuits marketed in Bangladesh. Bangladesh. J. Sci. Ind. Res. 2012, 47, 29-42. [CrossRef]

36. Patrignani, M.; Conforti, P.A.; Lupano, C.E. The role of lipid oxidation on biscuit texture during storage. Int. J. Food Sci. Technol. 2014, 49, 1925-1931. [CrossRef]

37. Hough, G.; Del Pilar Buera, M.; Chirife, J.; Moro, O. Sensory texture of commercial biscuits as a function of water activity. J Texture Stud. 2001, 32, 57-74. [CrossRef]

38. Pareyt, B.; Finnie, S.M.; Putseys, J.A.; Delcour, J.A. Lipids in bread making: Sources, interactions, and impact on bread quality. J. Cereal Sci. 2011, 54, 266-279. [CrossRef]

39. Secchi, N.; Stara, G.; Anedda, R.; Campus, M.; Piga, A.; Roggio, T.; Catzeddu, P. Effectiveness of sweet ovine whey powder in increasing the shelf life of Amaretti cookies. LWT Food Sci. Technol. 2011, 44, 1073-1078. [CrossRef]

40. Gould, G.W. Biodeterioration of foods and an overview of preservation in the food and dairy industries. Int. Biodeterior. Biodegrad. 1995, 8, 267-277. [CrossRef]

41. Szczesniak, A.S.; Kahan, E.L. Consumer awareness of and attitudes to food texture. I. Adults. J. Texture Stud. 1971, 2, 280-295. [CrossRef]

42. Tunick, M.H.; Onwulata, C.I.; Thomas, A.E.; Phillips, J.G.; Mukhopadhyay, S.; Sheen, S.; Liu, C.K.; Latona, N.; Pimentel, M.R.; Cooke, P.H. Critical Evaluation of Crispy and Crunchy Textures: A Review. Int. J. Food Prop. 2013, 16, 949-963. [CrossRef]

43. Piga, A.; Catzeddu, P.; Farris, S.; Roggio, T.; Sanguinetti, A.; Scano, E. Texture evolution of "Amaretti" cookies during storage. Eur. Food Res. Technol. 2005, 221, 387-391. [CrossRef]

44. Jacob, J.; Leelavathi, K. Effect of fat-type on cookie dough and cookie quality. J. Food Eng. 2007, 79, 299-305. [CrossRef]

45. Öksüz, T.; Karakaş, B. Sensory and textural evaluation of gluten-free biscuits containing buckwheat flour. Cogent Food Agric. 2016, 2,1178693

46. Torres González, J.D.; Torres Gallo, R.; Acevedo Correa, D.; Gallo-García, L.A.; Montero Castillo, P. Instrumental assessment of textural parameters of Colombian lemon biscuits. Contemp. Eng. Sci. 2018, 11, 1085-1102. [CrossRef]

47. Conte, P.; Pulina, S.; Del Caro, A.; Fadda, C.; Urgeghe, P.P.; De Bruno, A.; Difonzo, G.; Caponio, F.; Romeo, R.; Piga, A. Gluten-Free breadsticks fortified with phenolic-rich extracts from olive leaves and olive mill wastewater. Foods 2021, 10, 923. [CrossRef] [PubMed]

48. Goubgou, M.; Songré-Ouattara, L.T.; Bationo, F.; Banhoro, O.; Traoré, Y.; Savadogo, A. Effect of three types of oils and their level of incorporation on sensory quality of sorghum cookies. Food Res. 2021, 5, 190-202. [CrossRef]

49. Vukušić Pavičić, T.; Grgić, T.; Ivanov, M.; Novotni, D.; Herceg, Z. Influence of flour and fat type on dough rheology and technological characteristics of 3D-printed cookies. Foods 2021, 10, 193. [CrossRef] [PubMed]

50. Daglioglu, O.; Tasan, M.; Gecgel, U.; Daglioglu, F. Changes in oxidative stability of selected bakery products during shelf life. Food Sci. Technol. Res. 2004, 10, 464-468. [CrossRef]

51. Nagi, H.P.S.; Kaur, J.; Dar, B.N.; Sharma, S. Effect of storage period and packaging on the shelf life of cereal bran incorporated biscuits. Am. J. Food Technol. 2012, 7, 301-310. [CrossRef]

52. Zappia, A.; De Bruno, A.; Piscopo, A.; Poiana, M. Physico-chemical and microbiological quality of ready-to-eat rocket (Eruca vesicaria (L.) Cav.) treated with organic acids during storage in dark and light conditions. Food Sci. Biotechnol. 2019, 28, 965-973. [CrossRef]

53. Lipan, L.; Moriana, A.; López Lluch, D.B.; Cano-Lamadrid, M.; Nadal, E.S.; Hernández, F.; Vázquez-Araújo, L.; Corell, M.; Carbonell-Barrachina, Á.A. Nutrition quality parameters of almonds as affected by deficit irrigation strategies. Molecules 2019, 24, 2646. [CrossRef]

54. De Bruno, A.; Romeo, R.; Piscopo, A.; Poiana, M. Antioxidant quantification in different portions obtained during olive oil extraction process in an olive oil press mill. J. Sci. Food Agric. 2021, 101, 1119-1126. [CrossRef]

55. Omran, A.A.; Ibrahim, O.S.; El-Ola, Z.; Mohamed, M. Quality characteristics of biscuit prepared from wheat and flaxseed flour. Adv. Food Sci. 2016, 38, 129-138.

56. Bozkurt, F.; Baştürk, A. Farklı Depolama Sıcaklıklarının Kahvaltılık ve Mutfak Margarinlerinin Oksidatif Stabiliteleri Üzerine Etkileri. Yyü Tar Bil Derg, YYU J. Agric. Sci. 2018, 28, 103-111. [CrossRef] 
57. Schafer De Martini Soares, F.A.; Osório, N.M.; Claro da Silva, R.; Gioielli, L.A.; Ferreira-Dias, S. Batch and continuous lipasecatalyzed interesterification of blends containing olive oil for trans-free margarines. Eur. J. Lipid Sci. Technol. 2013, 115, 413-428. [CrossRef]

58. Caponio, F.; Giarnetti, M.; Paradiso, V.M.; Summo, C.; Gomes, T. Potential use of extra virgin olive oil in bakery products rich in fats: A comparative study with refined oils. Int. J. Food Sci. Technol. 2013, 48, 82-88. [CrossRef]

59. COI/T.15/NC No 3/Rev. 12 June 2018. Trade Standard Applying to Olive Oils and Olive Pomace Oils; International Olive Council: Madrid, Spain, 2018.

60. Ferreira Figueiroa, F.J.; De Marchi, F.E.; dos Santos, G.T.; dos Santos, W.B.R.; da Silva Kazama, D.C.; Cunha Leite, L.; Ferriani Branco, A.; Damasceno, J.C. Production, composition and fatty acid profile of milk and butter texture of dairy cows fed ground or pelleted concentrate with sunflower and/or lignosulfonate. R. Bras. Zootec. 2013, 42, 743-750. [CrossRef]

61. O'Callaghan, T.F.; Faulkner, K.; McAuliffe, H.; O'Sullivan, M.G.; Hennessy, D.; Dillon, P.; Kilcawley, K.N.; Stanton, C.; Ross, R.P. Quality characteristics, chemical composition, and sensory properties of butter from cows on pasture versus indoor feeding systems. J. Dairy Sci. 2016, 99, 9441-9460. [CrossRef]

62. FAO. Fats and Fatty Acids in Human Nutrition; Report of an Expert Consultation; FAO: Rome, Italy, 2010; ISBN 978-92-5-106733-8. Available online: https://www.who.int/nutrition/publications/nutrientrequirements/fatsandfattyacids_humannutrition/en/ (accessed on 18 September 2021).

63. Kim, H.; Youn, K.; Yun, E.Y.; Hwang, J.S.; Jeong, W.S.; Ho, C.H.T.; Jun, M. Oleic acid ameliorates A $\beta$-induced inflammation by downregulation of COX-2 and iNOS via NFkB signaling pathway. J. Funct. Foods 2015, 14, 1-11. [CrossRef]

64. Koczoń, P.; Lipińska, E.; Czerniawska-Piatkowska, E.; Mikuła, M.; Bartyzel, B.Z. The change of fatty acids composition of Polish biscuits during storage. Food Chem. 2016, 202, 341-348. [CrossRef]

65. Wasowicz, E.; Gramza, A.; Heś, M.; Jeleń, H.H.; Korczak, J.; Małecka, M.; Mildner-Szkudlarz, S.; Rudzińska, M.; Samotyja, U.; Zawirska-Wojtasiak, R. Oxidation of lipids in food. Pol. J. Food Nutr. Sci. 2004, 13, 87-100.

66. Mildner-Szkudlarz, S.; Zawirska-Wojtasiak, R.; Obuchowski, W.; Gośliński, M. Evaluation of antioxidant activity of green tea extract and its effect on the biscuits lipid fraction oxidative stability. J. Food Sci. 2009, 74, S362-S370. [CrossRef]

67. Culetu, A.; Ionescu, V.; Todasca, M.C.; Duta, D.E. Evaluation of the storage-associated changes in fatty acid profile of oat-based gluten-free cookies prepared with different fats. Food Sci. Biotechnol. 2020, 29, 759-767. [CrossRef] 